INTERNATIONAL

FOOD POLICY

RESEARCH

INSTITUTE

IFPRI

IFPRI Discussion Paper 01348

May 2014

\title{
An Evaluation of the Effectiveness of Farmland Protection Policy in China
}

Man Li

Environment and Production Technology Division 


\section{INTERNATIONAL FOOD POLICY RESEARCH INSTITUTE}

The International Food Policy Research Institute (IFPRI), established in 1975, provides evidence-based policy solutions to sustainably end hunger and malnutrition and reduce poverty. The Institute conducts research, communicates results, optimizes partnerships, and builds capacity to ensure sustainable food production, promote healthy food systems, improve markets and trade, transform agriculture, build resilience, and strengthen institutions and governance. Gender is considered in all of the Institute's work. IFPRI collaborates with partners around the world, including development implementers, public institutions, the private sector, and farmers' organizations, to ensure that local, national, regional, and global food policies are based on evidence.

\section{AUTHOR}

Man Li (man.li@ cgiar.org) is a research fellow in the Environment and Production Technology Division of the International Food Policy Research Institute, Washington, DC.

Notices

IFPRI Discussion Papers contain preliminary material and research results and are circulated in order to stimulate discussion and critical comment. They have not been subject to a formal external review via IFPRI's Publications Review Committee. Any opinions expressed are those of the author(s) and do not necessarily reflect the policies or opinions of IFPRI.

Copyright 2014 International Food Policy Research Institute. All rights reserved. Sections of this material may be reproduced for personal and not-for-profit use without the express written permission of but with acknowledgment to IFPRI. To reproduce the material contained herein for profit or commercial use requires express written permission. To obtain permission, contact the Communications Division at ifpri-copyright@cgiar.org. 


\section{Contents}

Abstract $\quad$ V

Acknowledgments $\quad$ vi

1. Introduction 1

2. Background of Farmland Protection in China and Lessons from Developed Countries 3

3. Modeling Urban Development in China 5

4. Results 13

5. Substitution Effects and Land Use Spillovers 22

6. Conclusions 24

Appendix A: Formulas of $\mathrm{T}_{0}$ and $\widehat{\mathrm{V}}_{0}\left(\mathrm{~T}_{0}\right)$ in the Cox-Pesaran Non-Nested Test 25

Appendix B: Supplementary Table 26

$\begin{array}{ll}\text { References } & 27\end{array}$ 


\section{Tables}

3.1 Summary statistics of variables used in evaluation analysis 10

4.1 Cross-sectional estimation with alternative land quality specification, 1986-1995 13

4.2. Cross-sectional estimation of farmland development, 1986-1995 15

4.3 Cross-sectional estimation of farmland development, 1995-2000 16

4.4 Cross-sectional estimation of farmland development, 2000-2005 17

4.5 First-differencing estimation of farmland development, 1995-2000 19

4.6 First-differencing estimation of farmland development, 2000-2005 20

5.1 Impact of farmland development on conversion of forests and grassland to farmland, 1986-2005 23

B.1 Summary statistics of variables used in estimation of substitution effects 26 


\begin{abstract}
Almost two decades have passed since China first enacted legislation to protect farmland from conversion to nonagricultural use. Yet hundreds of thousands of hectares of agricultural land are still developed to urban area each year, raising the question of whether the legislation is effective in preserving farmland from development. This paper examines the effectiveness of the Basic Farmland Protection Regulation in protecting high-quality farmland from urban development in China in the first decade after it came into effect (1995-2005). The theoretical basis for this study is a spatial urban development model with a splitting equation. The empirical evaluation is conducted with georeferenced, longitudinal data on more than 2,000 counties in the country. Results indicate that the Regulation was effective in preserving farmland with high productivity potential only during the period 1995-2000. There is no evidence of effectiveness of the Regulation in protecting lands with good irrigation conditions or lands more suitable for growing major food grains. Farmland development induces the conversion of non-farmland to crop production. This substitution effect declined from 1986 to 2005 and is therefore less likely to be exaggerated by the enforcement of the dynamic balance strategy.
\end{abstract}

\title{
Keywords: farmland protection, urban development, urban spatial model, non-nested hypothesis test, China
}

JEL classification: Q15, Q28, R14, R52 


\section{ACKNOWLEDGMENTS}

This paper was conducted under the CGIAR Research Program on Climate Change, Agriculture and Food Security (CCAFS). The author is indebted to JunJie Wu and Weidong Liu for their comments in the initial stage of the study design. The author gratefully acknowledges land use/cover data support from the Data Center for Resources and Environmental Sciences at the Chinese Academy of Sciences. 


\section{INTRODUCTION}

Farmland protection is among the top priorities of the Chinese government. On the one hand, food security is fundamental to the guarantee of national security and social stability in the country. On the other hand, the rapid urbanization that has accompanied China's remarkable economic growth has created intense competition for agricultural land in both urban fringe and rural areas. Almost two decades have passed since China first enacted legislation to protect farmland, especially high-quality cultivated land, from conversion to nonagricultural use. Yet hundreds of thousands of hectares of agricultural land are still converted to urban uses each year, raising the question of whether the legislation is effective in preserving farmland from development. The answer to this question has important implications for policymaking, which aims to find a proper balance between urban growth and farmland retention. This paper provides empirical insights into this question by focusing on the effectiveness of the Basic Farmland Protection Regulation.

The Basic Farmland Protection Regulation (hereafter the Regulation), passed in 1994 and amended in 1998, is one of the stringent laws on farmland conversion in China. As stipulated in the Regulation, local governments at the county level or higher are required to designate a basic farmland protection zone in every village or township. Conversion of farmland to nonagricultural uses is prohibited within the protection zones (State Council 1994; Lichtenberg and Ding 2008). If such conversion is unavoidable, it must be approved by the central or provincial government, and the loss of farmland must be offset by the same amount of new farmland somewhere else in the same county. The offset is referred to as the dynamic balance.

While its purpose is clear, the effects of the policy are ambiguous. The reasons are at least threefold. First, the total area of basic farmland was initially designated in each county, but the boundaries of those protected zones have never been revealed because doing so would affect the public image of government agencies and the performance appraisals of local officials. Under such circumstances, county government officials are more likely to target quantity than quality. Second, as part of its process of economic liberalization in pursuit of higher economic growth rates, China implemented a number of fiscal and governance reforms that appear to have pushed local officials to take on the role of land developer (Lichtenberg and Ding 2009), which is in conflict with their responsibility as executors of the Regulation. Third, it is not clear whether the enforcement of the dynamic balance strategy affects the rates of conversions of non-farmland to crop production. Yang and Li (2000) examine the national- and provincial-level changes in China's cultivated land for the period 1978-1996. They find that total cultivated land decreased from 1978 to 1994 but slightly increased from 1994 to 1996, due largely to reclamation, which coincided with the implementation of the dynamic balance strategy. A land use database derived from the U.S. Landsat imagery also presents evidence that despite large amounts of farmland lost to development, total farmland increased by 3.6 million hectares (ha) from 1995 to 2005. Conversions of grassland and forests to agricultural use are the primary source of the increase.

This paper develops a spatial urban development model and compiles a comprehensive nationwide, georeferenced database to empirically evaluate the effectiveness of the Regulation in the first decade after it came into effect (1995-2005). The model is built on the classic monocentric city model (Alonso 1964; Muth 1969; Mills 1967) and spatial urban growth model (Capozza and Helsley 1989). It uses pairwise non-nested hypothesis tests to assess the policy. The database contains accurate measurement of land use changes within each 1-kilometer $(\mathrm{km})$ grid cell over three land use transition periods (1986-1995, 1995-2000, and 2000-2005). The structure of these longitudinal data provides a way to measure the counterfactual in the evaluation. The land use data are merged with a set of land quality indicators and economic and geophysical variables. The combined data file is also used to investigate the potential substitution effects of farmland development on the conversion of forests and grassland. 
The paper's approach does not rely on the unobserved, ground-based data useful for identifying the basic farmland protection zones and therefore overcomes a major obstacle to the empirical evaluation of the Regulation. Lack of data has hindered efforts to assess this policy. To the best of the author's knowledge, this is the first time that either a researcher or a government agency has systematically evaluated the effectiveness of China's farmland protection policies on a national scale. In the existing literature, only a few studies document the issue, and they lack a detailed, systematic analysis (Lichtenberg and Ding 2008; Ding 2003; Yang and Li 2000). As increased attention is paid to the nexus of food security and urban development, a deeper understanding of the implications of farmland protection policy is necessary.

In this paper, the author demonstrates that by augmenting the classic spatial urban growth model with a splitting farmland preservation scheme and by taking advantage of the satellite remote-sensing land use data and geographic information system-derived land quality indicators, it is possible to perform statistical inference to assess the Regulation. The Chinese government is planning to conduct such assessments with a budget of approximately $¥ 600,000$ (around US\$98,000) per county; however, the approach proposed here requires a smaller investment in terms of cost, effort, and time. This is particularly important to a project or a developing country facing data scarcity and budget constraints. The approach presented here could be an important tool for policymakers responsible for managing urban growth and designing agricultural land protection policies.

The balance of evidence discussed in this paper suggests that the Regulation was effective in protecting farmland with high land productivity potential from urban development within a county during the period 1995-2000. A 1 percent increment in land productivity increases a land parcel's propensity to being preserved by around 2.8 percent. There is no evidence, however, of the effectiveness of the Regulation in preserving lands with good irrigation conditions or lands more suitable for growing rice, maize, and wheat. The Regulation was not effective in protecting farmland during the period 2000-2005, which coincided with the implementation of several economic development policies. Farmland development induces the conversion of forests and grassland to crop production. This substitution effect decreased from 0.14 percent before the enforcement of the dynamic balance strategy (1986-1995) to 0.02-0.07 percent after its implementation (1995-2005).

The remainder of this paper is organized as follows: Section 2 describes the background of farmland protection as well as lessons from developed countries. Section 3 describes the theoretical and empirical urban development models. Section 4 discusses the results. Section 5 explores the potential substitution effects of farmland development on non-farmland conversion. Section 6 concludes the paper. 


\section{BACKGROUND OF FARMLAND PROTECTION IN CHINA AND LESSONS FROM DEVELOPED COUNTRIES}

Urban growth in China began to accelerate in the late 1980s. From the late 1980s to the mid-1990s, the amount of urban built-up area in China increased by approximately 0.9 million ha (Liu et al. 2003). About 76 percent of the increase came from farmland characterized by high grain yield and a dense population, particularly in coastal regions. This led to a deteriorating national grain supply situation (OECD 1995). In response, China passed the Basic Farmland Protection Regulation in 1994 (State Council 1994), which imposes a set of strict administrative controls over farmland conversion.

\section{Farmland Protection Policies and Their Enforcement}

The Regulation requires that governments at the county level or higher designate a basic farmland protection zone in every village or township. Conversion of farmland to nonagricultural uses is not allowed within the protection zones. When a conversion is unavoidable, it must be approved by the provincial governments if the conversion is below a threshold amount of $500 \mathrm{mu}$ (around $33 \mathrm{ha}$ ) or by the State Council if the conversion is above that threshold. In addition, a dynamic balance instrument is imposed to offset the loss of farmland by the same amount of new farmland somewhere else in the same county (that is, no net loss). The Regulation applies to land planted to food grains, cotton, oilseeds, and vegetables, and to land with good irrigation, drainage, and erosion control, as well as experimental plots for agricultural research and development. The standards for basic farmland conversion were further tightened by the 1999 Amendments to the Land Administration Law (Standing Committee 1998), which require that any conversion of basic farmland be approved by the central government. In addition, the dynamic balance strategy applies to all farmland. (See Lichtenberg and Ding [2008] for an overview of farmland protection policies in China.)

In practice, governments use three indicators to monitor the implementation of these policies. The first is the acreage of total farmland (including basic farmland and nonbasic farmland), the second is the area of basic farmland, and the third is the ratio of the second indicator to the first indicator. The 1999 Amendments require that the ratio of basic farmland to total farmland be at least 80 percent in each provincial-level administrative district (Lichtenberg and Ding 2008).

\section{Lessons from Developed Countries}

The literature on public policies for managing urban growth and protecting agricultural land in developed countries is extensive (see Bengston et al. [2004] for a systematic review). These policies can be grouped into two broad categories - regulatory approaches and incentive-based approaches-and have been implemented at the local, regional, and, to a limited extent, national level. In the United States, for example, incentive-based approaches to the protection of agricultural land include right-to-farm laws, agricultural districts (voluntary enrollment), transfer of development rights, purchase of development rights, and use-value tax assessment, while regulatory instruments include subdivision exactions, clustered development, downzoning, and exclusive agricultural zoning. In particular, exclusive agricultural zoning, which conceptually bears similarities to the basic farmland protection zone in China, has been adopted in half of the 50 states in the country (American Farmland Trust 1997).

Despite the extensiveness of the literature describing policy instruments and programs, only a limited number of empirical studies have examined the effectiveness and impact of these policies (Bill and Boisvert 1987; Daniels 1998; Howe 1994; Kline and Alig 1999; Pfeffer and Lapping 1994; Wu and Cho 2007). Most of the evaluations are typically narrow in their focus (for example, targeting a specific program in a specific area). The lack of knowledge of the counterfactual poses a significant challenge to isolating and measuring the effects of a specific program, and changing social contexts also complicate the evaluation. 
One of the key lessons learned from the literature with regard to agricultural land protection is that the use of multiple reinforcing policy instruments is far more effective than relying on a single technique (Bengston et al. 2004). Jacobs's (1999) analysis and conclusion are similar. He examines agricultural land protection strategies in the Netherlands, Sweden, France, the United Kingdom, four provinces in Canada, three states in the United States, and Japan and finds strong similarity among the approaches adopted by those most successful countries and regions. In general, successful approaches require comprehensive planning by local governments, a system of strict land use regulation, and a means to purchase agricultural land threatened with conversion. In addition, the common factor among successful public programs to preserve agricultural land does not appear to be the actual policy strategies or approaches used, but instead how the strategies or approaches are used in a political policy environment that favors these land policies (Alterman 1997). 


\section{MODELING URBAN DEVELOPMENT IN CHINA}

To establish a framework providing empirically implementable tests of the effectiveness of the Basic Farmland Protection Regulation, this paper uses a modified version of the urban spatial model, which was pioneered by Alonso (1964), Muth (1969), and Mills (1967) and developed by a number of authors, most notably Arnott and Lewis (1979) and Capozza and Helsely (1989). The basic features of these models are that (1) the bid rent for land increases with urban household income and declines with distance from a center of economic activity such as a central business district (CBD); (2) at the city boundary, the bid rent equals agricultural rent, that is, the agricultural productivity of the land; and (3) land is developed when rent for urban use equals the opportunity cost of land conversion, including agricultural rent and conversion capital.

When adapting the urban spatial model to a developing country such as China, it is important to consider how well land markets operate. Land tenure in China is regulated by the Constitution, making the state the sole owner of urban lands and villagers the joint owners of rural lands. Land conversion from rural to urban use is possible only when local governments (county-level or higher) ${ }^{1}$ requisition land for development and other special uses by compensating villagers based on the land's agricultural productivity. Deng et al. (2008) examine several fundamental hypotheses generated by the monocentric urban model. Their investigation provides empirical evidence that the model has fairly high explanatory power when applied to China from the late 1980s to 2000. Lichtenberg and Ding (2009) also demonstrate that urban spatial expansions in China have become more responsive to economic incentives, even though the allocation of land between urban and rural uses is determined administratively.

Therefore, it is reasonable to initiate the analysis under the framework of the urban spatial model. In the present study, the county is used as the analytical unit because the county government is the lowest administration that has power to make urban development decisions.

\section{The Theoretical Model}

Consider how a county governor chooses land parcels for urban development. Without the Regulation, a parcel will be developed if

$$
\pi(w, r, a)>0
$$

where $\pi(\cdot)$ is the net returns to urban development, $w$ is the average urban household income, $r$ is the distance from the $\mathrm{CBD}$, and $a$ is the agricultural productivity of the parcel. Following the fundamental assumptions of the classic urban spatial model, one would expect that $\frac{\partial \pi}{\partial w}>0, \frac{\partial \pi}{\partial r}<0$, and $\frac{\partial \pi}{\partial a}<0$. In other words, for any given parcel, the net returns to urban development increase with urban household income and decrease with distance from the CBD and with land agricultural productivity.

Let $Y$ be a binary variable with values $0 / 1$, and $Y=0$ indicates that the parcel is not developed. Before the Regulation came into effect, the logit of the propensity $Y=0$ is equivalent to the logit of the propensity $\pi<0$, defined as the logarithm of the odds against $\pi>0$ :

$$
\operatorname{logit}(\operatorname{Pr}(Y=0))=\operatorname{logit}(\operatorname{Pr}(\pi<0)) \equiv \ln \frac{\operatorname{Pr}(\pi<0)}{\operatorname{Pr}(\pi>0)} .
$$

Equation (2) serves not only as a theoretical framework of land development without the Regulation but also as a counterfactual model when the Regulation takes effect.

\footnotetext{
${ }^{1}$ China has five levels of government: central, provincial, prefectural, county, and township. Township officials rank lowest in China's government hierarchy; they have little power to make land use conversion decisions. The village is an informal subdivision under the township, serving as a basic organizational unit for rural populations.
} 
The ideal analysis of the policy evaluation involves a treated group of basic farmland and a control group in which farmland conversion is not subject to the Regulation. In the absence of data useful for the identification of basic farmland, an appealing alternative is to introduce a latent variable $s$ that indicates whether a parcel locates in the protection zone. Conditioned on a set of variables $q, s$ is assumed to follow a Bernoulli distribution with parameter $\lambda$, where $\lambda$ is the probability of any given land parcel being classified into the protection area. $q$ is selected based on the criteria of designation of basic farmland such as land productivity, irrigation condition, and biophysical suitability indexes for major food grains. Let $\Lambda(\cdot)$ represent a cumulative logit probability. By definition, $\lambda=\Lambda(q \gamma)$. One may expect the marginal effects of $q$ on the probability of a land parcel being classified into the protection zone to be positive, that is, $\frac{\partial \Lambda(q \gamma)}{\partial q}>0$, which implies $\gamma>0 .^{2}$

The underlying rationale for introducing $s$ and $q$ is that the essence of the Regulation is to preserve high-quality farmland from conversion to nonagricultural use. If the Regulation is in effect, land parcels with higher agricultural productivity, with better irrigation conditions, or that are more suitable for growing major food grains such as rice, maize, and wheat would be more likely to be designated as basic farmland. Otherwise, the policy would eventually fail, even though land parcels classified as basic farmland were effectively protected.

Thus, under the Regulation, a parcel will be developed if

$$
\pi(w, r, a)>0 \text { and } s=0 .
$$

The distribution of indicator variable $Y$ can be specified accordingly:

$$
Y=\left\{\begin{array}{l}
0, \text { with probability } \lambda+(1-\lambda) \operatorname{Pr}(\pi<0) \\
1, \text { with probability }(1-\lambda) \operatorname{Pr}(\pi>0)
\end{array}\right.
$$

The concept underlying (4) is that zeroes are produced from two processes: one is structure and one is sampling. The structural zeros are generated from a Bernoulli distribution associated with $\lambda$ that governs some structure determining whether $Y$ has to be zero. The sampling zeros are observed due to a standard logit distribution associated with $\pi$, which assumes that the zero outcome happens by chance.

This framework borrows an idea from the zero-inflated model, a class of models for count data with the number of zeros unusually larger than would typically be predicted by a standard count data model such as a Poisson or a negative binomial model (see Lambert's [1992] seminal paper on the zeroinflated Poisson model). In a zero-inflated model, the presence of excess zeros is the consequence of a splitting mechanism. ${ }^{3}$ Zero-inflated models have been applied in many fields of empirical economics and other social sciences, such as manufacturing defects, consumer credit behavior, and demand for medical care (Lambert 1992; Greene 1994).

One can easily derive the logit of the propensity $Y=0$ from distribution (4):

\footnotetext{
$2 \frac{\partial \Lambda(q \gamma)}{\partial q}=\Lambda(q \gamma)[1-\Lambda(q \gamma)] \gamma$

${ }^{3}$ The zero-inflated model has a close resemblance to the hurdle model, but the two models are different in the interpretation of the source of the zero outcome (see Greene [1994] for an overview). For the former, the zero outcome arises from one of two regimes: in one regime, the outcome is always zero; in the other, the usual Poisson or negative binomial process is at work. For the hurdle model, however, the zero outcome is always generated by a process that is qualitatively different from the positive values.
} 


$$
\begin{aligned}
\operatorname{logit}(\operatorname{Pr}(Y=0)) \equiv & \ln \frac{\lambda+(1-\lambda) \operatorname{Pr}(\pi<0)}{(1-\lambda) \operatorname{Pr}(\pi>0)} \\
& =\ln \left[\frac{\operatorname{Pr}(\pi<0)}{\operatorname{Pr}(\pi>0)}\left(1+\frac{\lambda}{1-\lambda} \frac{1}{\operatorname{Pr}(\pi<0)}\right)\right] \\
& =\operatorname{logit}(\operatorname{Pr}(\pi<0))+\ln \left(1+\frac{e^{q \gamma}}{\operatorname{Pr}(\pi<0)}\right) .
\end{aligned}
$$

In this situation, the logit of the propensity $Y=0$ is no longer equivalent to the logit of the propensity $\pi<0$. The logit functions (2) and (5) are two competing models that serve as the theoretical basis for an econometric analysis to examine the effectiveness of the farmland protection policy. For convenience, this paper refers to (2) as an unaugmented model and to (5) as a zero-augmented model; equation $\lambda=$ $\Lambda(q \gamma)$ is named a splitting equation.

\section{Necessary Conditions for an Effective Policy}

The effectiveness of the farmland protection policy can be tested using two necessary conditions. First, model (2) is rejected in favor of model (5); second, in the splitting equation, the coefficient $\gamma$ is significantly positive. Condition one implies that under the Regulation, one would expect to observe an "excess" of land parcels staying in agricultural use, compared to the counterfactual in which there is no policy intervention. The second condition indicates that the excess farmland arises from a regime that is related to the criteria of designating basic farmland, that is, a land parcel that is more likely to be classified as basic farmland has a higher propensity to stay in farm use. These two conditions can be examined using statistical inference in the empirical analysis.

One issue arising in testing condition one is that the two competing models are non-nested. In (5), setting $\gamma$ to zero does not produce (2); it produces $\lambda=0.5$. Model (2) requires $\lambda$ to vanish, but this requires some element of $\gamma$ to explode. None of these is amenable to the familiar Wald or likelihood ratio test. To compare the two non-nested functional forms, this paper follows Cox $(1961,1962)$ and uses the $N$ ratio derived by Pesaran and Deaton (1978), which is well suited to the present nonlinear model.

Assuming that model (5) is the maintained hypothesis $\left(H_{0}\right)$ against model $(2)$, the Cox-Pesaran test statistic is

$$
N_{0}=\frac{T_{0}}{\sqrt{\widehat{V}_{0}\left(T_{0}\right)}}
$$

where $T_{0}$ is a modified $\log$-likelihood ratio and $\widehat{V}_{0}\left(T_{0}\right)$ is an estimate of variance of $T_{0}$. The formulas of $T_{0}$ and $\widehat{V}_{0}\left(T_{0}\right)$ are provided in Appendix A. Given that $H_{0}$ is valid, $N_{0}$ is asymptotically normally distributed with mean zero and variance one.

It is important that this $N$ test is not a measure of relative fit. $N_{0}$ provides a test of $H_{0}$ but tells us nothing about the validity of the alternative hypothesis $H_{1}$. If $N_{0}$ is significantly less than zero, one may conclude that $H_{0}$ is rejected in the direction of $H_{1}$; if $N_{0}$ is significantly greater than zero, one may conclude that $H_{0}$ is rejected in the direction away from $H_{1}$ (MacKinnon 1983). But one can never conclude from $N_{0}$ alone that $H_{0}$ is rejected in favor of $H_{1}$. To test the validity of $H_{1}$, one must reverse the roles of the two models and compute the test statistic $N_{1}$ (Pesaran and Deaton 1978).

Therefore, this paper calculates pairwise $N$ values to examine condition one. If the Regulation is in effect, one would expect that the $N$ statistic follows a standard normal distribution by taking (5) as $H_{0}$ against (2) and the $N$ statistic is significantly less than zero by taking (2) as $H_{0}$ against (5). 


\section{Data}

To create a dataset applicable to the present analysis, the author first compiled a geographic information system database that covers mainland China, including land use, economic variables, land quality, and topographic attributes, and then aggregated them to the county level.

\section{Land Use}

Land use data are originally derived from the U.S. Landsat Mapper/Enhanced Thematic Mapper scenes with a 30-meter spatial resolution. They are available for four time periods - the late 1980s (1986-1989), the mid-1990s (1995-1996), the late 1990s (1999-2000), and the middle years of the 2000-2010 decade (around 2005) - denoted as 1986, 1995, 2000, and 2005, respectively. These images are interpreted and digitized by the Data Center for Resources and Environmental Sciences at the Chinese Academy of Sciences (CAS) and are validated by extensive ground-based surveys (Liu et al. 2003; Liu et al. 2010). The average interpretative accuracy is in the range of 88-99.7 percent (Liu and Buheaosier 2000; Liu et al. 2003). The data are sorted using a hierarchical classification system of 25 land use classes, which are further grouped into six aggregated classes: farmland, forests, grassland, water area, urban built-up area, and unused land. Each class is presented as the number of hectares in a grid-cell extent for $1 \times 1 \mathrm{~km}$ at the equator.

This paper focuses the analysis on farmland and built-up area that is contiguous to urban settlements, industry, and roads (hereafter urban land). Given the dataset, it is easy to calculate changes in the area of urban land and farmland in each grid cell for three land use conversion periods, 1986-1995, 1995-2000, and 2000-2005, where the first period indicates the control period (without the intervention of the Regulation) and the last two periods indicate treated periods (after the Regulation came into force). The dataset does not provide information about land use conversion from one class to another within a grid cell. To derive the amount of farmland changed to urban use, the author first identifies land grids with increased urban land and decreased farmland during each transition period. ${ }^{4}$ According to von Thünen's location theory, agricultural activities are often conducted as close as possible to markets, which usually locate in urban centers. It is therefore reasonable to assume that urban development occurs first on farmland. In each grid cell, the acreage of farmland converted to urban use takes the smaller value of urban land increase or farmland decrease.

In addition to farmland conversion, two variables are generated from the land use database. One is the Euclidean distance from each grid cell to the nearest cell in which urban land is dominant. This variable serves as a proxy for distance to the urban boundary. The other is the percentage of land in each grid cell equipped for irrigation to grow aquatic crops, which is used to measure land irrigation conditions.

\section{Economic Variables}

Data on urban household income at the county level are generally lacking. Recent studies suggest that changes in urban area are increasing the value of urban land (Lichtenberg and Ding 2009; Li, Wu, and Deng 2013). Following the literature, this paper uses per hectare urban gross domestic product (GDP) as a proxy for the returns to urban development. County GDP figures by sector (agriculture, manufacturing, and services) are collected for three years $(1989,1996$, and 2000) from the National Bureau of Statistics of China (NBSC 2001). The author calculates per hectare urban GDP by dividing GDP in manufacturing and services by urban area in a county.

This paper includes public agricultural investment to reflect the opportunity costs of farmland development. The investments come from state and local governments and are used mainly for developing agriculture infrastructure such as seeds, fertilizers, and irrigation projects. The idea is that

\footnotetext{
${ }^{4}$ This paper does not consider the situation in which farmland is developed to urban use and the remaining lands are converted to farmland use, leading to increases in both urban land and farmland in a grid cell. Given that land is relatively homogeneous within a 1 - grid cell, this is less likely to happen because it would double the land use conversion costs.
} 
these investments could improve agricultural productivity and thus increase the opportunity costs of farmland conversion (Deng et al. 2008). Data on public agricultural investment are collected from province- and county-level statistical yearbooks and are available for four years (1994, 1995, 1999, and 2000). This paper uses the investments in 1994, the average of investments in 1995 and 1999, and investments in 2000, respectively, as proxies for the opportunity costs of farmland development in the three periods (1986-1995, 1995-2000, and 2000-2005).

\section{Land Quality}

Land quality is an important variable in assessing the farmland protection policy. While the Regulation designates general standards such as targeting major food grains and land with good irrigation in the effort to protect farmland from conversion, monitoring these indicators is difficult in practice. This study uses three location-specific indicators to measure land quality. The first is potential land productivity. This is a measure of dry plant matter and is developed by a research team from CAS using the stand-alone Estimation System for Land Productivity software (Deng et al. 2006). The second indicator is the irrigated percentage generated from the land use database, as discussed above. The third indicator is a vector of biophysical suitability indexes for rice, maize, and wheat, the three most important crops in China. These indexes are derived from the global Agro-ecological Zones (v1.0) assessment (Fischer et al. 2001) developed by the International Institute for Applied Systems Analysis and the Food and Agriculture Organization of the United Nations. This assessment has been widely applied because of its ability to provide a standardized framework for the effects of climate, soil, and terrain conditions, as well as socioeconomic factors relevant to agricultural production. Land productivity and suitability indexes are available at $10 \times 10 \mathrm{~km}$ at the equator. In the analysis that follows, this paper uses the three indicators separately to avoid collinearity.

\section{Topography}

This paper includes terrain elevation and slope as control variables in regression analysis. These variables are derived from a set of global terrain maps that are originally generated from the Shuttle Radar Topography Mission (90-meter resolution) and compiled by the International Institute for Applied Systems Analysis (Fischer et al. 2008). Elevation is presented as median elevation in each grid cell $(1 \times 1$ $\mathrm{km})$. Slope gradient is originally classified into nine categories on the global maps. The distributions of the nine classes are available for each grid cell. The author aggregates them into three groups-low slope ( $0-5$ percent), medium slope (5-15 percent), and high slope (>15 percent) - and assigns each grid cell to the group representing the largest proportion of that cell's area.

All geographic information system data (excluding economic variables) are aggregated from grid cell to county. The acreages of developed farmland and undeveloped farmland are the sums of the corresponding land use areas across land grid cells in a county. They are used to derive the left-hand-side variable in the regression. The remaining variables are calculated as weighted arithmetic means across land grid cells in a county. These variables are right-hand-side variables in the regression and are computed separately for each development status (developed or not developed). The weights are, respectively, the amount of developed farmland and undeveloped farmland in a grid cell. 
Table 3.1 Summary statistics of variables used in evaluation analysis

\begin{tabular}{|c|c|c|c|c|c|c|c|}
\hline Variable & Period & $N$ & $\begin{array}{l}\text { Development } \\
\text { status }\end{array}$ & Mean & $\begin{array}{l}\text { Standard } \\
\text { deviation }\end{array}$ & Minimum & Maximum \\
\hline \multirow{6}{*}{$\begin{array}{l}\text { Area of farmland } \\
\text { (thousand ha) }\end{array}$} & \multirow[t]{2}{*}{ 1986-1995 } & \multirow[t]{2}{*}{2,023} & Developed & 0.30 & 1.04 & 0 & 26.19 \\
\hline & & & Undeveloped & 76.11 & 60.67 & 0 & 494.81 \\
\hline & \multirow[t]{2}{*}{ 1995-2000 } & \multirow[t]{2}{*}{2,021} & Developed & 0.16 & 0.33 & 0 & 4.05 \\
\hline & & & Undeveloped & 75.58 & 63.38 & 0 & 529.98 \\
\hline & \multirow[t]{2}{*}{ 2000-2005 } & \multirow[t]{2}{*}{2,023} & Developed & 0.93 & 1.71 & 0 & 28.83 \\
\hline & & & Undeveloped & 76.69 & 64.99 & 0 & 573.99 \\
\hline \multirow{3}{*}{$\begin{array}{l}\text { Per hectare urban } \\
\text { GDP (million } ¥ / \mathrm{ha} \text { ) }\end{array}$} & 1986-1995 & 2,023 & - & 0.09 & 0.33 & 0 & 12.82 \\
\hline & 1995-2000 & 2,021 & - & 0.19 & 0.87 & 0 & 25.32 \\
\hline & 2000-2005 & 2,023 & - & 0.24 & 0.73 & 0 & 20.02 \\
\hline \multirow{3}{*}{$\begin{array}{l}\text { Agricultural } \\
\text { investment (ten } \\
\text { thousand } ¥ \text { ) }\end{array}$} & 1985-1995 & 2,023 & - & 7.41 & 38.26 & 0 & $1,178.31$ \\
\hline & 1995-2000 & 2,021 & - & 7.54 & 41.24 & 0 & $1,335.41$ \\
\hline & 2000-2005 & 2,023 & - & 9.46 & 52.26 & 0 & $1,705.73$ \\
\hline \multirow{6}{*}{$\begin{array}{l}\text { Distance from urban } \\
\text { boundary }(\mathrm{km})\end{array}$} & \multirow[t]{2}{*}{ 1986-1995 } & \multirow[t]{2}{*}{2,023} & Developed & 9.29 & 17.51 & 0.00 & 163.75 \\
\hline & & & Undeveloped & 17.83 & 15.03 & 1.67 & 162.29 \\
\hline & \multirow[t]{2}{*}{ 1995-2000 } & \multirow[t]{2}{*}{2,021} & Developed & 9.39 & 16.84 & 0.00 & 163.43 \\
\hline & & & Undeveloped & 17.09 & 14.57 & 0.74 & 162.20 \\
\hline & \multirow[t]{2}{*}{ 2000-2005 } & \multirow[t]{2}{*}{2,023} & Developed & 12.01 & 13.89 & 0.52 & 198.73 \\
\hline & & & Undeveloped & 16.39 & 13.08 & 0.62 & 162.59 \\
\hline \multirow{6}{*}{$\begin{array}{l}\text { Land productivity } \\
\text { (ten metric tons/ha) }\end{array}$} & \multirow[t]{2}{*}{ 1986-1995 } & \multirow[t]{2}{*}{2,023} & Developed & 0.396 & 0.330 & 0 & 1.390 \\
\hline & & & Undeveloped & 0.400 & 0.301 & 0 & 1.380 \\
\hline & \multirow[t]{2}{*}{ 1995-2000 } & \multirow[t]{2}{*}{2,021} & Developed & 0.399 & 0.330 & 0 & 1.398 \\
\hline & & & Undeveloped & 0.400 & 0.301 & 0 & 1.379 \\
\hline & \multirow[t]{2}{*}{ 2000-2005 } & \multirow[t]{2}{*}{2,023} & Developed & 0.414 & 0.311 & 0 & 1.380 \\
\hline & & & Undeveloped & 0.400 & 0.301 & 0 & 1.379 \\
\hline \multirow[t]{6}{*}{ Irrigation (\%) } & 1986-1995 & 2,023 & Developed & $19 \%$ & $24 \%$ & $0 \%$ & $94 \%$ \\
\hline & & & Undeveloped & $20 \%$ & $23 \%$ & $0 \%$ & $97 \%$ \\
\hline & 1995-2000 & 2,021 & Developed & $20 \%$ & $24 \%$ & $0 \%$ & $95 \%$ \\
\hline & & & Undeveloped & $20 \%$ & $23 \%$ & $0 \%$ & $96 \%$ \\
\hline & 2000-2005 & 2,023 & Developed & $22 \%$ & $24 \%$ & $0 \%$ & $90 \%$ \\
\hline & & & Undeveloped & $20 \%$ & $22 \%$ & $0 \%$ & $96 \%$ \\
\hline Biophysical & 1986-1995 & 2,023 & Developed & 0.19 & 0.22 & 0 & 0.80 \\
\hline rice (ranging from 0 & & & Undeveloped & 0.18 & 0.20 & 0 & 0.66 \\
\hline 1) & 1995-2000 & 2,021 & Developed & 0.19 & 0.22 & 0 & 0.79 \\
\hline & & & Undeveloped & 0.18 & 0.20 & 0 & 0.66 \\
\hline & 2000-2005 & 2,023 & Developed & 0.20 & 0.21 & 0 & 0.75 \\
\hline & & & Undeveloped & 0.19 & 0.20 & 0 & 0.65 \\
\hline $\begin{array}{l}\text { Biophysical } \\
\text { suitability index for }\end{array}$ & 1986-1995 & 2,023 & Developed & 0.45 & 0.23 & 0 & 1.00 \\
\hline maize (ranging from & & & Undeveloped & 0.45 & 0.20 & 0 & 0.98 \\
\hline $0-1)$ & 1995-2000 & 2,021 & Developed & 0.45 & 0.23 & 0 & 1.00 \\
\hline & & & Undeveloped & 0.45 & 0.20 & 0 & 0.98 \\
\hline & 2000-2005 & 2,023 & Developed & 0.45 & 0.21 & 0 & 0.99 \\
\hline & & & Undeveloped & 0.45 & 0.20 & 0 & 0.98 \\
\hline
\end{tabular}


Table 3.1 Continued

\begin{tabular}{|c|c|c|c|c|c|c|c|}
\hline Variable & Period & $N$ & $\begin{array}{l}\text { Development } \\
\text { status }\end{array}$ & Mean & $\begin{array}{l}\text { Standard } \\
\text { deviation }\end{array}$ & Minimum. & Maximum \\
\hline \multirow{6}{*}{$\begin{array}{l}\text { Biophysical } \\
\text { suitability index for } \\
\text { wheat (ranging from } \\
0-1 \text { ) }\end{array}$} & \multirow[t]{2}{*}{ 1986-1995 } & \multirow[t]{2}{*}{2,023} & Developed & 0.44 & 0.22 & 0 & 1.00 \\
\hline & & & Undeveloped & 0.44 & 0.19 & 0 & 0.96 \\
\hline & \multirow[t]{2}{*}{ 1995-2000 } & \multirow[t]{2}{*}{2,021} & Developed & 0.44 & 0.22 & 0 & 1.00 \\
\hline & & & Undeveloped & 0.44 & 0.19 & 0 & 0.96 \\
\hline & \multirow[t]{2}{*}{ 2000-2005 } & \multirow[t]{2}{*}{2,023} & Developed & 0.44 & 0.20 & 0 & 0.97 \\
\hline & & & Undeveloped & 0.44 & 0.19 & 0 & 0.96 \\
\hline \multirow[t]{6}{*}{ Elevation (km) } & \multirow[t]{2}{*}{ 1986-1995 } & \multirow[t]{2}{*}{2,023} & Developed & 0.55 & 0.72 & 0 & 4.08 \\
\hline & & & Undeveloped & 0.61 & 0.73 & -0.02 & 4.08 \\
\hline & \multirow[t]{2}{*}{ 1995-2000 } & \multirow[t]{2}{*}{2,021} & Developed & 0.56 & 0.71 & 0 & 3.94 \\
\hline & & & Undeveloped & 0.61 & 0.73 & -0.02 & 3.91 \\
\hline & \multirow[t]{2}{*}{ 2000-2005 } & \multirow[t]{2}{*}{2,023} & Developed & 0.55 & 0.71 & 0 & 4.08 \\
\hline & & & Undeveloped & 0.61 & 0.73 & -0.01 & 4.08 \\
\hline \multirow{6}{*}{$\begin{array}{l}\text { Medium slope }(0-1 \\
\text { dummy, where } 1 \\
\text { indicates } 5 \% \leq \\
\text { slope } \leq 15 \%)\end{array}$} & \multirow[t]{2}{*}{ 1986-1995 } & \multirow[t]{2}{*}{2,023} & Developed & 0.30 & 0.39 & 0 & 1 \\
\hline & & & Undeveloped & 0.46 & 0.38 & 0 & 1 \\
\hline & \multirow[t]{2}{*}{ 1995-2000 } & \multirow[t]{2}{*}{2,021} & Developed & 0.31 & 0.39 & 0 & 1 \\
\hline & & & Undeveloped & 0.46 & 0.38 & 0 & 1 \\
\hline & \multirow[t]{2}{*}{ 2000-2005 } & \multirow[t]{2}{*}{2,023} & Developed & 0.32 & 0.35 & 0 & 1 \\
\hline & & & Undeveloped & 0.47 & 0.38 & 0 & 1 \\
\hline \multirow{6}{*}{$\begin{array}{l}\text { High slope }(0-1 \\
\text { dummy, where } 1 \\
\text { indicates slope }> \\
15 \%)\end{array}$} & \multirow[t]{2}{*}{ 1986-1995 } & \multirow[t]{2}{*}{2,023} & Developed & 0.18 & 0.34 & 0 & 1 \\
\hline & & & Undeveloped & 0.31 & 0.35 & 0 & 1 \\
\hline & \multirow[t]{2}{*}{ 1995-2000 } & \multirow[t]{2}{*}{2,021} & Developed & 0.18 & 0.32 & 0 & 1 \\
\hline & & & Undeveloped & 0.31 & 0.35 & 0 & 1 \\
\hline & \multirow[t]{2}{*}{ 2000-2005 } & \multirow[t]{2}{*}{2,023} & Developed & 0.19 & 0.29 & 0 & 1 \\
\hline & & & Undeveloped & 0.32 & 0.35 & 0 & 1 \\
\hline
\end{tabular}

Source: Author's calculations.

Note: $\quad$ ha $=$ hectare; $\mathrm{km}=$ kilometer.

Missing data reduced the usable sample to 2,023 counties for the time periods 1986-1995 and 2000-2005 and to 2,021 counties for the period 1995-2000. Table 3.1 reports summary statistics of these variables by development status and by land use conversion period.

\section{The Empirical Model}

For each county, there are two types of explanatory variables. The first type is the economic variables that are county-specific but invariant to whether a parcel is developed within a county. Let $x$ be a vector of choice-invariant variables and $x=$ (per hectare urban GDP, public agricultural investment). Separate coefficients, $\beta_{x 0}$ and $\beta_{x 1}$, are estimated for each choice, where $\beta_{x 0}$ and $\beta_{x 1}$ are associated with $\pi_{i}<0$ and $\pi_{i}>0$, respectively. ${ }^{5}$ The subscript $i$ is an index of the county.

The second type of variables includes land quality and topographic attributes, which vary not only by county but also across land development choices. In this case, county average values are calculated separately for each choice, but their coefficients stay same. Let $z=$ (distance from urban

\footnotetext{
${ }^{5}$ This paper avoids using $Y$ to indicate the choice because when the Regulation is in effect, $Y$ possibly consists of some zero outcomes arising from the splitting equation that is irrelevant to $x$.
} 
boundary, elevation, slope) and let $z$ be a vector of choice-specific explanatory variables and $z_{i 0}$ and $z_{i 1}$ be their county average values associated with $\pi_{i}<0$ and $\pi_{i}>0$, respectively. The same coefficient vector $\beta_{z}$ is estimated for both choices.

Given the specification discussed above, the propensity of $\pi_{i}<0$ is written as

$$
\operatorname{Pr}\left(\pi_{i}<0\right)=\frac{e^{\beta_{00}+x_{i} \beta_{x 0}+z_{i 0} \beta_{z}}}{e^{\beta_{00}+x_{i} \beta_{x 0}+z_{i 0} \beta_{z}}+e^{\beta_{01}+x_{i} \beta_{x 1}+z_{i 1} \beta_{z}}} .
$$

Without loss of generality, this paper uses $\pi_{i}>0$ as a reference and normalizes the choice-specific coefficients and explanatory variables with this status such that $\beta_{0}^{*} \equiv \beta_{00}-\beta_{01}, \beta_{x}^{*} \equiv \beta_{x 0}-\beta_{x 1}$, and $z_{i}^{*} \equiv z_{i 0}-z_{i 1}$. These normalizations imply

$$
\operatorname{Pr}\left(\pi_{i}<0\right)=\Lambda\left(\beta_{0}^{*}+x_{i} \beta_{x}^{*}+z_{i}^{*} \beta_{z}\right)
$$

Accordingly, without the intervention of the Regulation, the logit of the propensity $Y_{i}=0$ is nothing but the logit of the propensity $\pi_{i}<0$,

$$
\operatorname{logit}\left(\operatorname{Pr}\left(Y_{i}=0\right)\right)=\beta_{0}^{*}+x_{i} \beta_{x}^{*}+z_{i}^{*} \beta_{z}
$$

When the Regulation takes effect, the logit of the propensity $Y_{i}=0$ can be derived from equations (5) and (8):

$$
\operatorname{logit}\left(\operatorname{Pr}\left(Y_{i}=0\right)\right)=\beta_{0}^{*}+x_{i} \beta_{x}^{*}+z_{i}^{*} \beta_{z}+\ln \left[1+\frac{e^{q_{i} \gamma}}{\Lambda\left(\beta_{0}^{*}+x_{i} \beta_{x}^{*}+z_{i}^{*} \beta_{z}\right)}\right] .
$$

Equations (9) and (10) are the empirical counterparts to the theoretical models (2) and (5). Equation (10) is estimated using quasi-Newton optimization methods. 


\section{RESULTS}

The correct specification of equations (9) and (10) is in itself an empirical question. Given that (10) is built on (9), this section first identifies the specification of (9) using data from the control period 19861995. Then it estimates (9) and (10) separately for all three land use transition periods and applies pairwise Cox-Pesaran tests to compare (9) and (10). Finally, it uses the first-difference approach to control the potential unobserved, time-invariant factors that are correlated with land development decisions and one or more of the explanatory variables. Those factors may arise from individuals' intrinsic history, culture, county size, special location, or institutional factors.

\section{Identification}

Identification of (9) starts with a specification that consists of per hectare urban GDP, public agricultural investment, distance from the urban boundary, topography control variables, and a constant (column 1, Table 4.1), and incrementally adds three alternative land quality indicators (columns 2-4) and 30 province dummies (columns 5-8) to the model.

Table 4.1 Cross-sectional estimation with alternative land quality specification, 1986-1995

\begin{tabular}{|c|c|c|c|c|c|c|c|c|}
\hline \multirow[b]{2}{*}{ Variable } & \multicolumn{8}{|c|}{ Dependent variable: $\operatorname{Logit}\left(\operatorname{Pr}\left(\mathrm{Y}_{1986-95}=0\right)\right)$} \\
\hline & (1) & (2) & (3) & $(4)$ & (5) & (6) & (7) & (8) \\
\hline $\begin{array}{l}\text { Per hectare urban } \\
\text { GDP }\end{array}$ & $0.920^{* *}$ & $0.917^{* *}$ & $0.922^{* *}$ & $0.925^{* *}$ & $0.846^{* * *}$ & $0.846^{* \star \star}$ & $0.846^{* * *}$ & $0.833^{* * *}$ \\
\hline $\begin{array}{l}\text { Agricultural } \\
\text { investment }\end{array}$ & $-0.007^{* *}$ & $-0.007^{* *}$ & $-0.007^{* *}$ & $-0.007^{* *}$ & $-0.009^{* * * *}$ & $-0.009^{* \star *}$ & $-0.009^{* * *}$ & $-0.009^{* * *}$ \\
\hline Land productivity & & -1.221 & & & & -0.0002 & & \\
\hline Irrigation & & & $-3.156^{\star * *}$ & & & & 0.0056 & \\
\hline Rice & & & & -1.541 & & & & 1.411 \\
\hline Maize & & & & 0.372 & & & & $-3.279^{* *}$ \\
\hline Wheat & & & & 0.720 & & & & 1.016 \\
\hline Distance & $-0.132^{* \star *}$ & $-0.132^{* * *}$ & $-0.130^{\star * *}$ & $-0.132^{* * *}$ & $-0.132^{* * * *}$ & $-0.132^{* * *}$ & $-0.132^{* * *}$ & $-0.133^{\star \star *}$ \\
\hline Elevation & -0.916 & -1.037 & -1.327 & -1.027 & $-2.622^{* * * *}$ & $-2.622^{* * * *}$ & $-2.621^{* * *}$ & $-2.694^{* * *}$ \\
\hline Slope_medium & $-3.071^{* \star *}$ & $-3.152^{* * *}$ & $-3.313^{* * \star}$ & $-3.127^{* \star *}$ & $-1.575^{* * *}$ & $-1.575^{* * *}$ & $-1.574^{* * *}$ & $-1.524^{* * *}$ \\
\hline Slope_high & 0.445 & 0.409 & 0.065 & 0.431 & $-1.766^{* * *}$ & $-1.766^{* * * *}$ & $-1.766^{\star * *}$ & $-1.784^{* * *}$ \\
\hline $\begin{array}{l}\text { Constant } \\
\text { Province }\end{array}$ & $10.783^{* * *}$ & $10.807^{*+*}$ & $10.920^{* * *}$ & $10.788^{* * *}$ & $23.114^{* * *}$ & $23.114^{* * * *}$ & $23.114^{* * *}$ & $23.115^{* * *}$ \\
\hline dummies & No & No & No & No & Yes & Yes & Yes & Yes \\
\hline$N$ & 2,023 & 2,023 & 2,023 & 2,023 & 2,023 & 2,023 & 2,023 & 2,023 \\
\hline $\begin{array}{l}\text { Adjusted } R \text { - } \\
\text { squared }\end{array}$ & 0.080 & 0.081 & 0.086 & 0.081 & 0.444 & 0.444 & 0.444 & 0.446 \\
\hline
\end{tabular}

Source: Author's calculations.

Note: GDP = gross domestic product. *, **, and *** indicate statistical significance at the $10 \%, 5 \%$, and $1 \%$ levels, respectively. 
The identification provides empirical evidence for the three fundamental assumptions of the classic urban spatial model. After controlling for topographic variables, farmland is more likely to be developed in counties with higher urban land value or lower agricultural investment, or when a parcel is close to the urban boundary. As land quality indicators and province dummy variables are incrementally added to the model, the importance of the three variables persists and the magnitude of the coefficient changes little. $F$-tests reject the null that province fixed effects are jointly equal to zero. But there is no robust evidence to support the association of land quality indicators with land development decisions. Therefore, variables listed in column 5 of Table 4.1 are chosen as the specification of the unaugmented equation in the following analysis.

\section{Cross-Sectional Analysis}

Tables 4.2-4.4 present the results from the estimation of equations (9) and (10), using data from the periods 1986-1995, 1995-2000, and 2000-2005, respectively. In all three tables, column 1 corresponds to the unaugmented model (9), and columns 2-4 correspond to the zero-augmented model (10), in which three land quality indicators are specified separately in the splitting equation. The Cox-Pesaran test statistics are reported at the bottom of the tables. A comparison of the results in column 1 and columns $2-$ 4 indicates that including the splitting equation does not change the sign and significance of variables specified in the unaugmented equations for all three periods.

To explore the effectiveness of the Regulation, the author first examines the $N$ ratios for the treated periods 1995-2000 and 2000-2005, during which the farmland protection policy was in force. One would expect the tests to reject model (9) in favor of model (10). Given the three alternative land quality indicators, there are three pairwise non-nested hypotheses for each time period. Taking (9) as the maintained hypothesis $\left(H_{0}\right)$ first, the $N$ ratio, which is asymptotically distributed as $N(0,1)$ under $H_{0}$, respectively takes values of $-57.5,-51.4$, and -52.5 for the period $1995-2000$ and the values of -44.6 , 33.6, and -44.7 for the period 2000-2005. This implies that model (9) is rejected in the direction of model (10). The author then reverses the procedure and takes (10) as the maintained hypothesis, which leads to an $N$ ratio of $-0.8,-1.34$, and -0.96 for the period $1995-2000$ and $-1.37,-1.31$, and -1.12 for the period 2000-2005. Clearly, model (10) cannot be rejected. Therefore, the test results indicate that the unaugmented model (9) is rejected in favor of the zero-augmented model (10), which is consistent with condition one as discussed in Section 3.

The effectiveness of the Regulation is judged not only by the model structure but also by the coefficient estimates of alternative land quality indicators in the splitting equations. When the Regulation is effective, one would expect these coefficients to be significantly positive (condition two). In the empirical estimation for the two treated periods, however, all the variables are significantly negative except the biophysical index for wheat (see Tables 4.3 and 4.4). Thus, condition two is not satisfied in the two treated periods. Considering that the Regulation is imposed down to each county, and land quality is heterogeneous across counties, this result is not surprising. ${ }^{6}$

\footnotetext{
${ }^{6}$ The present result reveals a limitation of the policy design—protecting high-quality farmland within each county does not imply that high-quality farmland can be effectively preserved nationwide. The Regulation would be more effective if it were to take into account heterogeneity in land quality across counties.
} 
Table 4.2. Cross-sectional estimation of farmland development, 1986-1995

\begin{tabular}{|c|c|c|c|c|c|c|c|c|}
\hline \multirow[b]{2}{*}{ Variable } & \multicolumn{8}{|c|}{ Dependent variable: $\operatorname{Logit}\left(\operatorname{Pr}\left(Y_{1986-95}=0\right)\right)$} \\
\hline & \multicolumn{2}{|l|}{$(1)$} & \multicolumn{2}{|l|}{$(2)$} & \multicolumn{2}{|l|}{ (3) } & \multicolumn{2}{|l|}{$(4)$} \\
\hline \multicolumn{9}{|l|}{ Splitting equation } \\
\hline \multirow[t]{2}{*}{ Land productivity } & & & -4.027 & *** & & & & \\
\hline & & & $(0.323)$ & & & & & \\
\hline \multirow[t]{2}{*}{ Irrigation } & & & & & -3.525 & *** & & \\
\hline & & & & & $(0.484)$ & & & \\
\hline \multirow[t]{2}{*}{ Rice } & & & & & & & -4.474 & $* * *$ \\
\hline & & & & & & & $(0.576)$ & \\
\hline \multirow[t]{2}{*}{ Maize } & & & & & & & -9.414 & 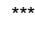 \\
\hline & & & & & & & $(0.708)$ & \\
\hline \multirow[t]{2}{*}{ Wheat } & & & & & & & 5.321 & 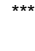 \\
\hline & & & & & & & $(0.721)$ & \\
\hline \multirow[t]{2}{*}{ Constant } & & & 8.796 & *** & 7.609 & $* * *$ & 10.001 & *** \\
\hline & & & $(0.184)$ & & $(0.147)$ & & $(0.327)$ & \\
\hline \multicolumn{9}{|l|}{ Unaugmented equation } \\
\hline \multirow[t]{2}{*}{ Per hectare urban GDP } & 0.846 & *** & 1.177 & $* * \star$ & 1.228 & *** & 1.053 & *** \\
\hline & $(0.309)$ & & $(0.365)$ & & $(0.362)$ & & $(0.362)$ & \\
\hline \multirow[t]{2}{*}{ Ag. investment } & -0.009 & *** & -0.054 & *** & -0.059 & $* \star *$ & -0.052 & *** \\
\hline & $(0.003)$ & & $(0.020)$ & & $(0.019)$ & & $(0.020)$ & \\
\hline \multirow[t]{2}{*}{ Distance } & -0.132 & *** & -0.317 & $* \star \star$ & -0.313 & $* * *$ & -0.320 & *** \\
\hline & $(0.013)$ & & $(0.023)$ & & $(0.021)$ & & $(0.023)$ & \\
\hline \multirow[t]{2}{*}{ Elevation } & -2.622 & *** & -13.037 & $* * \star$ & -12.180 & $* \star *$ & -12.040 & *** \\
\hline & $(0.883)$ & & $(1.569)$ & & $(1.497)$ & & $(1.551)$ & \\
\hline \multirow[t]{2}{*}{ Slope_medium } & -1.575 & ${ }^{* * *}$ & -3.479 & *** & -3.791 & *** & -3.873 & ${ }^{* \star *}$ \\
\hline & $(0.485)$ & & $(1.064)$ & & $(0.993)$ & & $(1.068)$ & \\
\hline \multirow[t]{2}{*}{ Slope_high } & -1.766 & $* * *$ & -8.510 & $* * *$ & -8.400 & $* * *$ & -8.433 & *** \\
\hline & $(0.553)$ & & $(1.126)$ & & $(1.036)$ & & $(1.108)$ & \\
\hline Province dummies & Yes & & Yes & & Yes & & Yes & \\
\hline$N$ & 2,023 & & 2,023 & & 2,023 & & 2,023 & \\
\hline Adjusted $R$-squared & 0.444 & & 0.549 & & 0.527 & & 0.555 & \\
\hline Cox test for unaugmented model & - & & -44.6 & $* \star \star$ & -36.9 & *** & -44.7 & *** \\
\hline Cox test for zero-augmented model & - & & -3.2 & *** & -2.9 & *** & -2.5 & ** \\
\hline
\end{tabular}

Source: Author's calculations

Note: GDP = gross domestic product; Ag. = agricultural. Column 1 corresponds to the unaugmented model and columns $2-4$ correspond to the zero-augmented model with alternative land quality indicators specified in the splitting equation. *, **, and $* * *$ indicate statistical significance at the $10 \%, 5 \%$, and $1 \%$ levels, respectively. 
Table 4.3 Cross-sectional estimation of farmland development, 1995-2000

\begin{tabular}{|c|c|c|c|c|c|c|c|c|}
\hline \multirow[b]{2}{*}{ Variable } & \multicolumn{8}{|c|}{ Dependent variable: $\operatorname{Logit}\left(\operatorname{Pr}\left(Y_{1995-2000}=0\right)\right)$} \\
\hline & \multicolumn{2}{|c|}{ (1) } & (2) & \multicolumn{2}{|c|}{ (3) } & \multicolumn{3}{|c|}{ (4) } \\
\hline \multicolumn{9}{|l|}{ Splitting equation } \\
\hline \multirow[t]{2}{*}{ Land productivity } & & & -3.128 & $\star \star \star *$ & & & & \\
\hline & & & $(0.328)$ & & & & & \\
\hline \multirow[t]{2}{*}{ Irrigation } & & & & & -2.216 & $* \star *$ & & \\
\hline & & & & & $(0.432)$ & & & \\
\hline \multirow[t]{2}{*}{ Rice } & & & & & & & -2.822 & *** \\
\hline & & & & & & & $(0.546)$ & \\
\hline \multirow[t]{2}{*}{ Maize } & & & & & & & -4.729 & *** \\
\hline & & & & & & & $(0.692)$ & \\
\hline \multirow[t]{2}{*}{ Wheat } & & & & & & & 3.420 & *** \\
\hline & & & & & & & $(0.723)$ & \\
\hline \multirow[t]{2}{*}{ Constant } & & & 8.515 & $* \star *$ & 7.630 & $* * *$ & 8.396 & *** \\
\hline & & & $(0.178)$ & & $(0.141)$ & & $(0.306)$ & \\
\hline \multicolumn{9}{|l|}{ Unaugmented equation } \\
\hline \multirow[t]{2}{*}{ Per hectare urban GDP } & 0.515 & $* * *$ & 0.967 & $* \star *$ & 0.958 & $* * *$ & 0.926 & $* * *$ \\
\hline & $(0.120)$ & & $(0.169)$ & & $(0.177)$ & & $(0.168)$ & \\
\hline \multirow[t]{2}{*}{ Ag. investment } & -0.009 & $* * *$ & -0.140 & $* *$ & -0.142 & $* * *$ & -0.142 & *** \\
\hline & $(0.003)$ & & $(0.027)$ & & $(0.028)$ & & $(0.027)$ & \\
\hline \multirow[t]{2}{*}{ Distance } & -0.131 & $* \star \star$ & -0.397 & $* * *$ & -0.411 & $* * *$ & -0.401 & $* * *$ \\
\hline & $(0.014)$ & & $(0.026)$ & & $(0.026)$ & & $(0.026)$ & \\
\hline \multirow[t]{2}{*}{ Elevation } & -5.095 & $* * *$ & -22.273 & $* * *$ & -22.520 & $* * \star$ & -22.704 & *** \\
\hline & $(0.971)$ & & $(2.020)$ & & $(2.007)$ & & (2.049) & \\
\hline \multirow[t]{2}{*}{ Slope_medium } & -1.205 & ** & -2.870 & ** & -3.232 & $* * *$ & -2.854 & ** \\
\hline & $(0.501)$ & & $(1.212)$ & & $(1.208)$ & & $(1.220)$ & \\
\hline \multirow[t]{2}{*}{ Slope_high } & -2.903 & $* * *$ & -12.051 & $* \star \star$ & -12.227 & $* * *$ & -12.312 & $* *$ \\
\hline & $(0.585)$ & & (1.362) & & (1.352) & & (1.375) & \\
\hline Province dummies & Yes & & Yes & & Yes & & Yes & \\
\hline$N$ & 2,021 & & 2,021 & & 2,021 & & 2,021 & \\
\hline Adjusted $R$-squared & 0.358 & & 0.517 & & 0.501 & & 0.509 & \\
\hline Cox test for unaugmented model & - & & -57.5 & $* * *$ & -51.4 & *** & -52.5 & $* * \star$ \\
\hline Cox test for zero-augmented model & - & & -0.80 & & -1.34 & & -0.96 & \\
\hline
\end{tabular}

Source: Author's calculations

Note: GDP = gross domestic product; Ag. = agricultural. Column 1 corresponds to the unaugmented model and columns $2-4$ correspond to the zero-augmented model with alternative land quality indicators specified in the splitting equation. *, **, and $* * *$ indicate statistical significance at the $10 \%, 5 \%$, and $1 \%$ levels, respectively. 
Table 4.4 Cross-sectional estimation of farmland development, 2000-2005

\begin{tabular}{|c|c|c|c|c|c|c|c|c|}
\hline \multirow[b]{2}{*}{ Variable } & \multicolumn{8}{|c|}{ Dependent variable: $\operatorname{Logit}\left(\operatorname{Pr}\left(Y_{2000-05}=0\right)\right)$} \\
\hline & \multicolumn{2}{|c|}{ (1) } & \multicolumn{2}{|c|}{ (2) } & \multicolumn{2}{|l|}{ (3) } & \multicolumn{2}{|l|}{ (4) } \\
\hline \multicolumn{9}{|l|}{ Splitting equation } \\
\hline \multirow[t]{2}{*}{ Land productivity } & & & -4.105 & $* * *$ & & & & \\
\hline & & & $(0.552)$ & & & & & \\
\hline \multirow[t]{2}{*}{ Irrigation } & & & & & -2.884 & $* * *$ & & \\
\hline & & & & & $(0.298)$ & & & \\
\hline \multirow[t]{2}{*}{ Rice } & & & & & & & -3.933 & *** \\
\hline & & & & & & & $(1.020)$ & \\
\hline \multirow[t]{2}{*}{ Maize } & & & & & & & -4.552 & $* * *$ \\
\hline & & & & & & & $(0.667)$ & \\
\hline \multirow[t]{2}{*}{ Wheat } & & & & & & & 2.098 & *** \\
\hline & & & & & & & $(0.505)$ & \\
\hline \multirow[t]{2}{*}{ Constant } & & & 2.375 & *** & 4.005 & $* *$ & 2.304 & *** \\
\hline & & & $(0.255)$ & & $(0.301)$ & & $(0.348)$ & \\
\hline \multicolumn{9}{|l|}{ Unaugmented equation } \\
\hline \multirow[t]{2}{*}{ Per hectare urban GDP } & -0.016 & & -0.010 & & 0.052 & & -0.022 & \\
\hline & $(0.055)$ & & $(0.054)$ & & $(0.072)$ & & $(0.055)$ & \\
\hline \multirow[t]{2}{*}{ Ag. investment } & -0.003 & $* *$ & -0.006 & $* *$ & -0.018 & $* * *$ & -0.006 & 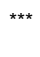 \\
\hline & $(0.001)$ & & $(0.001)$ & & $(0.005)$ & & $(0.001)$ & \\
\hline \multirow[t]{2}{*}{ Distance } & -0.010 & & -0.016 & ** & -0.019 & ** & -0.013 & * \\
\hline & $(0.008)$ & & $(0.007)$ & & $(0.008)$ & & $(0.008)$ & \\
\hline \multirow[t]{2}{*}{ Elevation } & 1.520 & $* * *$ & 0.825 & ** & 0.717 & * & 1.264 & *** \\
\hline & $(0.413)$ & & $(0.407)$ & & $(0.437)$ & & $(0.407)$ & \\
\hline \multirow[t]{2}{*}{ Slope_medium } & -1.187 & $* * *$ & -1.196 & $* * *$ & -1.421 & $* * *$ & -1.219 & *** \\
\hline & $(0.303)$ & & $(0.301)$ & & $(0.361)$ & & $(0.299)$ & \\
\hline \multirow[t]{2}{*}{ Slope_high } & -0.142 & & -0.562 & * & -0.706 & * & -0.348 & \\
\hline & $(0.330)$ & & $(0.326)$ & & $(0.368)$ & & $(0.326)$ & \\
\hline Province dummies & Yes & & Yes & & Yes & & Yes & \\
\hline$N$ & 2,023 & & 2,023 & & 2,023 & & 2,023 & \\
\hline Adjusted $R$-squared & 0.377 & & 0.412 & & 0.406 & & 0.401 & \\
\hline Cox test for unaugmented model & - & & -44.6 & $* * *$ & -36.6 & $* * *$ & -44.7 & *** \\
\hline Cox test for zero-augmented model & - & & -1.37 & & -1.31 & & -1.12 & \\
\hline
\end{tabular}

Source: Author's calculations

Note: GDP = gross domestic product; Ag. = agricultural. Column 1 corresponds to the unaugmented model and columns $2-4$ correspond to the zero-augmented model with alternative land quality indicators specified in the splitting equation. *, **, and $* * *$ indicate statistical significance at the $10 \%, 5 \%$, and $1 \%$ levels, respectively.

As a robustness check, the author repeats the test procedure for the control period 1986-1995, during which one would expect model (10) to not be valid because the Regulation has not been put into effect. When (10) is the maintained hypothesis against (9), the $N$ ratio returns $-3.2,-2.9$, and -2.5 , implying that (10) is rejected in the direction of (9). Setting (9) to the maintained hypothesis against (10), however, leads to an $N$ ratio of $-44.6,-36.9$, and -44.7 and to the conclusion that the true model deviates 
from (9) in the direction of (10). Consequently, we are left without a satisfactory model for this period. ${ }^{7}$ This may be due to the relative simplicity of the model. Given that decisionmaking for land development is a complicated process that is likely to be affected by some institutional factors that are not captured in the model, the explanatory power of model (9) is limited. Even so, this test demonstrates that there is no evidence of a splitting scheme that governs whether or not a parcel of farmland is to be preserved, which is completely different from the test results for the two treated periods.

\section{Accounting for Time-Invariant Unobservables}

Let us now turn to the first-difference models to account for potential unobserved, time-invariant factors. Assuming that model (9) is true for the control period, if (9) is still valid under the Regulation, subtracting the observations from the two treated periods from the observations from the control period yields a firstdifference unaugmented model

$$
\Delta \operatorname{logit}\left(\operatorname{Pr}\left(Y_{i}=0\right)\right)=\Delta x_{i} \beta_{x}^{*}+\Delta z_{i}^{*} \beta_{z}
$$

where $\Delta \operatorname{logit}\left(\operatorname{Pr}\left(Y_{i}=0\right)\right)=\operatorname{logit}\left(\operatorname{Pr}\left(Y_{i t}=0\right)\right)-\operatorname{logit}\left(\operatorname{Pr}\left(Y_{i c}=0\right)\right), \Delta x_{i}=x_{i t}-x_{i c}$, and $\Delta z_{i}^{*}=z_{i t}^{*}-$ $z_{i c}^{*}$; the subscripts $t$ and $c$ represent treated and control periods, respectively. Similarly, if model (10) is true under the Regulation, taking differences gives a first-difference zero-inflated model

$$
\Delta \operatorname{logit}\left(\operatorname{Pr}\left(Y_{i}=0\right)\right)=\Delta \boldsymbol{x}_{i} \beta_{x}^{*}+\Delta \boldsymbol{z}_{i}^{*} \beta_{z}+\ln \left[1+\frac{e^{q_{i t} \gamma}}{\Lambda\left(\beta_{0}^{*}+x_{i t} \beta_{x}^{*}+z_{i t}^{*} \beta_{z}\right)}\right] .
$$

Province dummy variables are retained in equations (11) and (12) to control for unobserved, time-variant factors within a province. Models (11) and (12) are estimated separately for the two treated periods.

The estimation results, reported in Tables 4.5 and 4.6, indicate that the unaugmented equations are generally robust to first differences except the two economic variables. ${ }^{8}$ More interesting are the results derived from policy assessment, which indicate that the two conditions necessary for an effective Regulation are satisfied given the data from 1995-2000 and the model with land productivity potential specified in the splitting equation combined.

\footnotetext{
${ }^{7}$ Given the rejection of models (9) and (10) in the reciprocal directions, the true model is possibly in the middle.

${ }^{8}$ One possible reason is that those economic variables are correlated to county individual effects. This result may admittedly indicate possible biases in the coefficient estimates of two economic variables reported in Tables 4.2-4.4, but it would not matter too much because this paper is mostly interested in examining the model structure and the coefficient estimates of land quality indicators.
} 
Table 4.5 First-differencing estimation of farmland development, 1995-2000

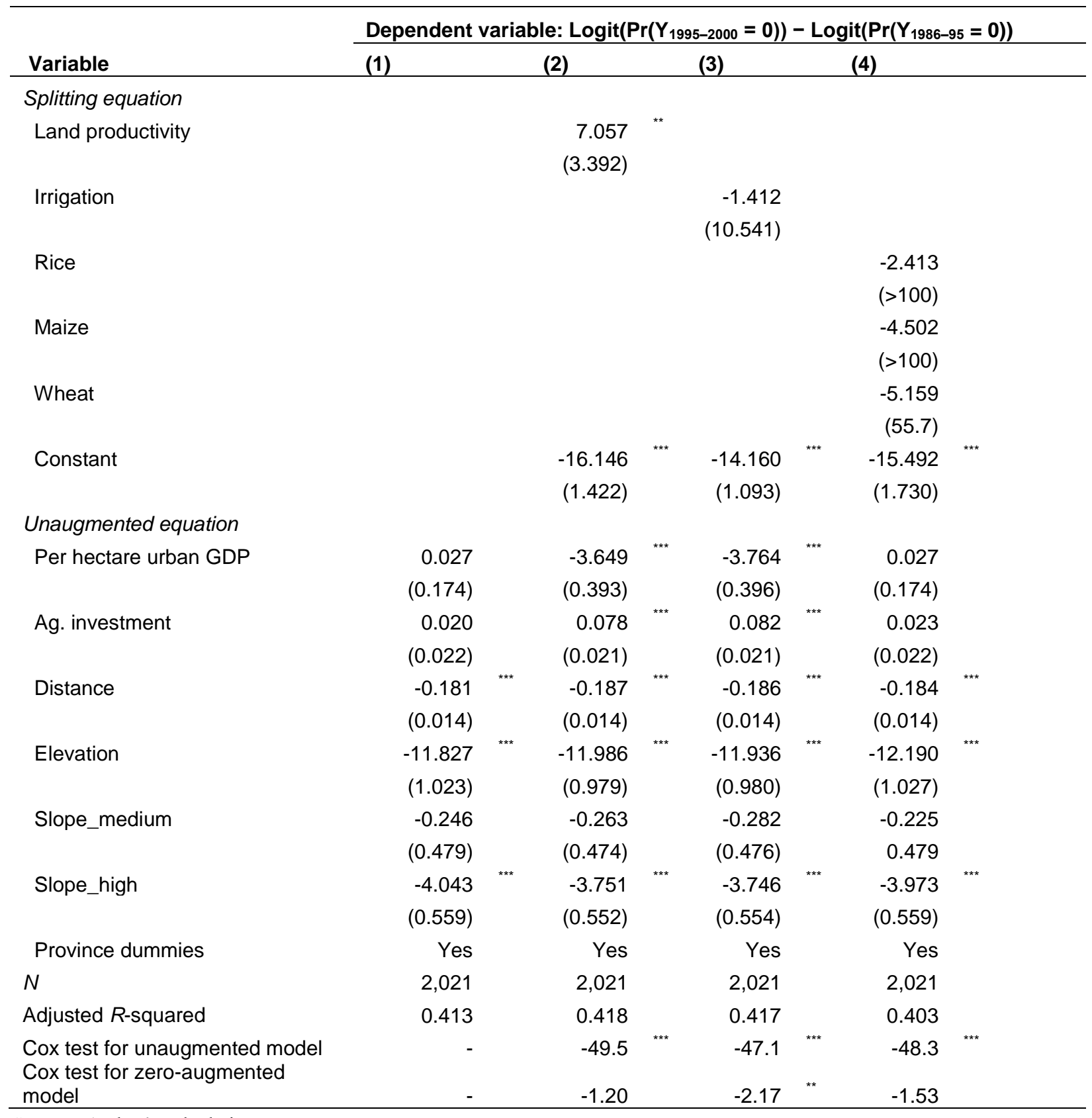

Source: Author's calculations

Note: Column 1 corresponds to the unaugmented model and columns 2-4 correspond to the zero-augmented model with alternative land quality indicators specified in the splitting equation. *,**, and *** indicate statistical significance at the $10 \%, 5 \%$, and $1 \%$ levels, respectively. 
Table 4.6 First-differencing estimation of farmland development, 2000-2005

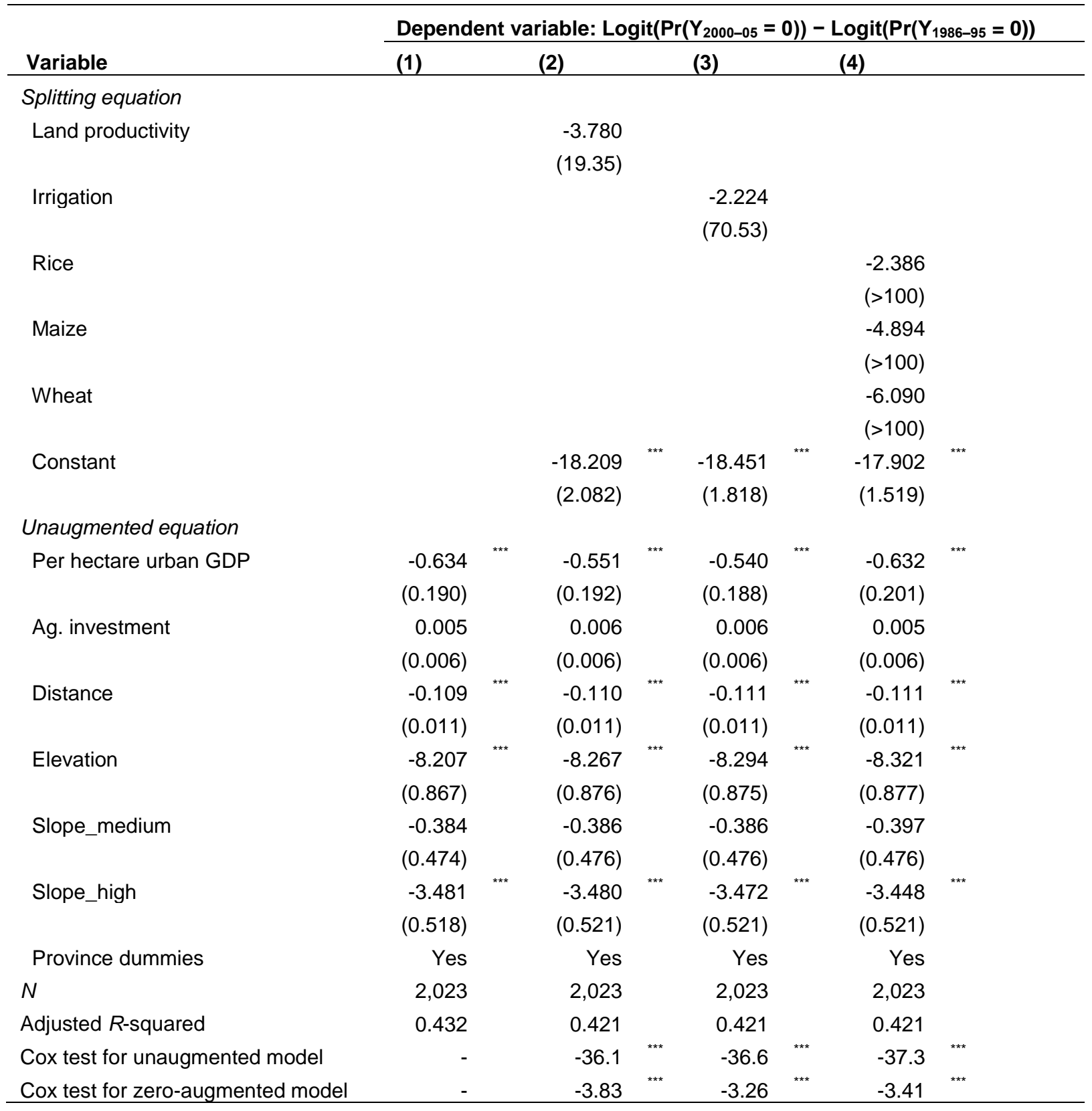

Source: Author's calculations

Note: GDP = gross domestic product. Column 1 corresponds to the unaugmented model and columns $2-4$ correspond to the zero-augmented model with alternative land quality indicators specified in the splitting equation. *, **, and *** indicate statistical significance at the $10 \%, 5 \%$, and $1 \%$ levels, respectively.

Not surprisingly, taking (11) as the maintained hypothesis, all $N$ ratios are significantly negative, leading to the rejection of model (11) in the direction of (12). When one reverses the sequence and takes (12) as the maintained hypothesis against (11), however, the $N$ values are different from the results produced from the cross-sectional models in the previous section. For the period 1995-2000, the $N$ ratio takes a value of $-1.2,-2.17$, and -1.53 (columns $2-4$, Table 4.5 ), implying that model (12) cannot be rejected when the land quality indicator is measured by land productivity potential or biophysical suitability indexes, but it can be rejected when land quality is measured by irrigated percentage. For the 
period 2000-2005, the $N$ ratio returns $-3.83,-3.26$, and -3.41 (columns $2-4$, Table 4.6). This leads to the rejection of model (12) in the direction of (11).

By looking at the coefficient estimates of all land quality indicators in the splitting equations reported in Tables 4.5 and 4.6, one can find the coefficient on land productivity estimated to be 7.057 at the 5 percent level for the period 1995-2000. In other words, a 1 percent increment in land productivity increases a land parcel's propensity to being designated as basic farmland by around 2.8 percent (the elasticity is evaluated at the sample mean). This positive value is consistent with the second condition necessary for an effective Regulation. The remaining estimates are still negative but statistically insignificant.

Therefore, the balance of evidence from this section suggests that the Regulation was effective in preserving farmland with high land productivity potential within a county during the period 1995-2000. The selection of preserved parcels is less likely to be based on irrigation conditions or biophysical suitability for rice, maize, and wheat. There is no evidence of the effectiveness of the Regulation in farmland protection in the period 2000-2005, regardless of land quantity or quality. These findings are generally consistent with the descriptive statistics summarized from the satellite remote-sensing land use database. A total of 0.73 million ha of farmland were lost to development from 1986 to 1995. The amount decreased to 0.39 million ha in the period 1995-2000 but increased again in the period 2000-2005, during which the developed farmland reached 2.22 million ha, almost twice as much as the total conversion from 1986 to 2000

\section{Importance of Favorable Socioeconomic Context}

A comparison of Tables 4.5 and 4.6 reveals stark differences in the policy effectiveness between the two treated periods, which brings out the importance of a favorable socioeconomic environment for farmland protection. The Regulation was less successful in the period 2000-2005, although the central government reinforced this policy in the 1999 Amendments. Possibly this lack of success was not because of the policy instrument itself, but rather because the Regulation was implemented in a socioeconomic context that did not favor the policy.

This period coincides with the implementation of several economic development policies. For example, China launched housing monetization reform in 1998 to replace the long-standing in-kind housing subsidy and targeted the housing industry as "a new growth focus" (Lee and Zhu 2006). China also made a tremendous investment in road construction. The country's total road length increased almost 2.5-fold, from 1.4 million kilometers in 2000 to 3.46 million kilometers in 2006 (NBSC 2010). Further investigations of the impacts of these development strategies on farmland protection are beyond the scope of this study. Nonetheless, these development strategies appear to enhance the role of local officials in land development, making the top-down farmland protection policy less effective.

The observations in this paper are similar to Jacobs's (1999) and Alterman's (1997) analyses of agricultural land protection strategies in Western countries. Both note that success in agricultural land protection is less strongly related to the characteristics of the particular approaches taken and instead is more a factor of the sociopolitical environment that supports it. Thus, creating a socioeconomic and political policy environment that is capable of reconciling the conflict between economic development and farmland retention is a key consideration for policymakers. 


\section{SUBSTITUTION EFFECTS AND LAND USE SPILLOVERS}

Urbanization has many secondary ripple effects. It may induce conversion of non-farmland, especially forests and grassland, to crop production due to substitution effects. When some farmland is converted to development, farmers may either voluntarily substitute other land for crop production because of economies of scale, fixed input effects, or market schemes (Wu 2000) or be required by the administrative order to offset the loss of farmland by the same amount of new farmland somewhere else, which is referred to as dynamic balance in the Regulation.

This section explores the potential substitution effects of farmland development on the conversion of forests and grassland (hereafter non-farmland) using a multivariate regression analysis:

$$
\ln \Delta N F_{i t}=\alpha_{i}+\alpha_{t}+\theta_{1} \ln \Delta F_{i t}+\theta_{2} V_{i t}+\varepsilon_{i t}
$$

where $\alpha_{i}$ and $\alpha_{t}$ are, respectively, cross-sectional fixed effects and time fixed effects; $i$ is an index of the county; $t$ is an index of the land use conversion period between 1986 and 2005; $\ln \Delta N F_{i t}$ and $\ln \Delta F_{i t}$ are, respectively, the logarithm of the acreage of non-farmland converted to farmland and the logarithm of the acreage of farmland converted to urban use during each period; and $V_{i t}$ is a vector consisting of rural population, the ratio of per capita urban-to-rural GDP, elevation, terrain slope, precipitation, and temperature. The substitution effects are measured by $\theta_{1}$, the elasticity of $\Delta N F$ with respect to $\Delta F$, defined as the percentage change in converted non-farmland acreage caused by a 1 percent change in developed farmland acreage.

Acreage of non-farmland converted to farmland is derived from the land use database using a procedure similar to that applied to derive the area of farmland converted to development as described in the data section. Rural population data are collected from the Ministry of Public Security of China (MPSC 1996, 2001). This variable serves as a measure of pressure on forests and grassland. The ratio of per capita urban-to-rural GDP is calculated by dividing urban GDP per nonrural resident by rural GDP per rural resident. A high ratio indicates a large urban-rural income disparity. This variable is used to capture the effect of rural-to-urban migration on land use conversions. In a region with a larger urban-rural income gap, rural laborers are more likely to move to cities to work, which tends to relieve pressure on converting non-farmland to crop production. Annual climate data between 1991 and 2005 were initially collected from more than 600 weather stations and were interpolated by CAS from the point data into surface data. This paper calculates the average values of annual precipitation and mean annual temperature for each county and each land use conversion period. Summary statistics of all these variables are presented in Appendix B.

To examine the presence of potential substitution effects and whether the effects change over time, this paper considers three specifications. The first specification is a one-way fixed effects model in which cross-sectional fixed effects are included. The second specification is a two-way fixed effects model in which both cross-sectional and time effects are considered. Finally, this study takes into account the interaction of substitution effects and time effects. If the enforcement of the dynamic balance strategy exaggerated non-farmland conversion, one would expect the interaction terms to be significantly positive for the treated periods. Table 5.1 presents the estimation results using data from all the counties over the three periods. The columns correspond to specifications 1-3, reading from left to right. 
Table 5.1 Impact of farmland development on conversion of forests and grassland to farmland, 1986-2005

\begin{tabular}{|c|c|c|c|c|c|c|}
\hline \multirow[b]{2}{*}{ Variable } & \multicolumn{6}{|c|}{$\begin{array}{l}\text { Dependent variable: Ln(area of forests/grassland converted to } \\
\text { farmland) }\end{array}$} \\
\hline & (1) & & (2) & & (3) & \\
\hline $\begin{array}{l}\text { Ln(area of developed } \\
\text { farmland) }\end{array}$ & $0.101^{* * *}$ & $(0.014)$ & $0.092^{* * *}$ & $(0.014)$ & $0.145^{* * *}$ & $(0.016)$ \\
\hline $\begin{array}{l}\text { Time fixed effects }(1995- \\
\text { 2000) }\end{array}$ & & & -1.219 & $(0.136)$ & $-1.205^{\star \star \star}$ & $(0.138)$ \\
\hline $\begin{array}{l}\text { Time fixed effects }(2000- \\
\text { 2005) }\end{array}$ & & & $-0.245^{* *}$ & $(0.116)$ & $-0.399^{* * * *}$ & $(0.118)$ \\
\hline $\begin{array}{l}\text { Ln(area of developed } \\
\text { farmland) } \times \text { time effects } \\
(1995-2000)\end{array}$ & & & & & $-0.077^{-\cdots *}$ & $(0.017)$ \\
\hline $\begin{array}{l}\text { Ln(area of developed } \\
\text { farmland) } \times \text { time effects } \\
(2000-2005)\end{array}$ & & & & & $-0.125^{m *}$ & $(0.019)$ \\
\hline Ln(rural population) & $2.401^{* * *}$ & $(0.261)$ & $1.835^{* * *}$ & $(0.260)$ & $1.678^{* * *}$ & $(0.260)$ \\
\hline $\begin{array}{l}\text { Ratio of per capita urban- } \\
\text { to-rural GDP }\end{array}$ & -0.006 & $(0.004)$ & $-0.012^{\cdots}$ & $(0.004)$ & $-0.011^{\cdots}$ & $(0.004)$ \\
\hline Elevation & $-0.966^{* * *}$ & $(0.336)$ & $-0.821^{* *}$ & $(0.331)$ & $-0.787^{* * *}$ & (0.329) \\
\hline Slope_medium & 0.482 & $(0.327)$ & $0.535^{*}$ & $(0.322)$ & $0.549^{*}$ & $(0.320)$ \\
\hline Slope_high & -0.368 & $(0.345)$ & -0.278 & $(0.339)$ & -0.281 & $(0.337)$ \\
\hline Precipitation & $-3.268^{* * *}$ & $(0.925)$ & $-5.676^{* * *}$ & (1.102) & $-6.185^{* * *}$ & $(1.100)$ \\
\hline Precipitation squared & $1.678^{* * *}$ & $(0.373)$ & $2.343^{* * *}$ & $(0.390)$ & $2.383^{* * *}$ & $(0.388)$ \\
\hline Temperature & $1.136^{* * *}$ & $(0.096)$ & $0.888^{* *+*}$ & $(0.096)$ & $0.726^{* * *}$ & $(0.100)$ \\
\hline Temperature squared & -0.004 & $(0.004)$ & $-0.023^{* * *}$ & $(0.005)$ & $-0.018^{* * *}$ & $(0.005)$ \\
\hline County fixed effects & Yes & & Yes & & Yes & \\
\hline Degree of freedom & 4,458 & & 4,456 & & 4,454 & \\
\hline Adj. R-squared & 0.684 & & 0.696 & & 0.699 & \\
\hline
\end{tabular}

Source: Author's calculations

Note: $\quad * * *$, and $* * *$ indicate statistical significance at the $10 \%, 5 \%$, and $1 \%$ levels, respectively.

Results from column 1 suggest that farmland development fosters the conversion of non-farmland to crop production. Holding other variables constant, a 1 percent increase in the acreage of developed farmland would induce an approximately 0.1 percent increase in non-farmland conversion. Columns 2 and 3 report the results from incrementally adding time fixed effects and the interaction of substitution effects and time effects to the specification, respectively. In both cases, $F$-tests reject the null that additional parameters are jointly equal to zero. Including time fixed effects alone does not change the estimate of substitution effects by much. When accounting for the interaction terms, however, the estimation results suggest that the substitution effects decrease significantly over time. Given a 1 percent increase in the area of developed farmland, the converted non-farmland acreage is estimated to increase by about 0.14 percent for the period 1986-1995, 0.07 percent for the period 1995-2000, and 0.02 percent for the period 2000-2005. Therefore, there is no evidence that substitution effects are exaggerated by the enforcement of the dynamic balance instrument. 


\section{CONCLUSIONS}

This paper evaluates the effectiveness of China's Basic Farmland Protection Regulation in protecting high-quality farmland from urban development in the first decade after it became law (1995-2005). The study employs a spatial urban development model with a splitting equation. Although the model does not include an explicit variable for the regulatory policy, it is capable of examining the presence of the farmland preservation scheme by using pairwise non-nested hypothesis tests. The model is characterized by a low data requirement for the unobserved, ground-based data useful for the identification of basic farmland zones. While collecting information on basic farmland is very laborious and costly, the present paper provides informative insights into the effectiveness of the policy on a national scale. This study selects three representative indictors to measure land quality. The analysis can be easily extended to other land quality indicators listed in the Regulation.

Results indicate that the Regulation was effective in protecting farmland with high productivity potential from urban development during the period 1995-2000. Given a 1 percent increase in land productivity potential, the probability of a land parcel being preserved increases by about 2.8 percent. There is no evidence of the effectiveness of the Regulation in preserving lands with good irrigation conditions or lands more suitable for growing rice, maize, and wheat. The Regulation was not effective in protecting farmland during the period 2000-2005, regardless of land quantity or quality.

Farmland development induces the conversion of non-farmland to crop production. The substitution effect decreased from 0.14 percent before the implementation of the dynamic balance strategy (1986-1995) to 0.02-0.07 percent after the policy instrument was enforced (1995-2005). Therefore, the substitution effect is less likely to be enlarged by the dynamic balance policy. 


\section{APPENDIX A: FORMULAS OF $\mathrm{T}_{0}$ AND $\widehat{\mathrm{V}}_{0}\left(\mathrm{~T}_{0}\right)$ IN THE COX-PESARAN NON-NESTED TEST}

For simplicity, assume the model to be tested is

$$
\begin{gathered}
H_{0}: y=f\left(\theta_{0} ; X\right)+u_{0}, u_{0} \sim N I D\left(0, \sigma_{0}^{2} I\right) \text { and } \\
H_{1}: y=g\left(\theta_{1} ; Z\right)+u_{1}, u_{1} \sim N I D\left(0, \sigma_{1}^{2} I\right),
\end{gathered}
$$

where $y$ is a vector of observations on the $N$ dependent variables, $f(\cdot)$ and $g(\cdot)$ are the corresponding vectors of predictions, $u_{0}$ and $u_{1}$ of errors, and $X$ and $Z$ are matrixes of predetermined variables.

Let $\hat{\theta}_{0}$ and $\hat{\theta}_{1}$ be the maximum likelihood estimates of $\theta_{0}$ and $\theta_{1}$, and $\hat{\sigma}_{0}^{2}$ and $\hat{\sigma}_{1}^{2}$ of $\sigma_{0}^{2}$ and $\sigma_{1}^{2}$. By definition,

$$
\begin{gathered}
\hat{\sigma}_{0}^{2}=\frac{1}{N}\left(y-f\left(\hat{\theta}_{0}\right)\right)^{\prime}\left(y-f\left(\hat{\theta}_{0}\right)\right) \text { and } \\
\hat{\sigma}_{1}^{2}=\frac{1}{N}\left(y-g\left(\hat{\theta}_{1}\right)\right)^{\prime}\left(y-g\left(\hat{\theta}_{1}\right)\right) .
\end{gathered}
$$

Let $\hat{\theta}_{10}$ be an estimate of $\theta_{1}$ under $H_{0}$, given by

$$
\hat{\sigma}_{10}^{2}=\hat{\sigma}_{0}^{2}+\frac{1}{N}\left(f\left(\hat{\theta}_{0}\right)-g\left(\hat{\theta}_{1}\right)\right)^{\prime}\left(f\left(\hat{\theta}_{0}\right)-g\left(\hat{\theta}_{1}\right)\right) .
$$

The Cox test statistic is simply

$$
T_{0}=\frac{N}{2} \ln \frac{\widehat{\sigma}_{1}^{2}}{\widehat{\sigma}_{10}^{2}}
$$

An estimate of the variance of $T_{0}$ is obtained from the formula

$$
\widehat{V}_{0}\left(T_{0}\right)=\frac{\widehat{\sigma}_{0}^{2}}{\widehat{\sigma}_{10}^{4}}\left(f\left(\hat{\theta}_{0}\right)-g\left(\hat{\theta}_{1}\right)\right)^{\prime}\left(I-\hat{F}\left(\hat{F}^{\prime} \hat{F}\right)^{-1} \hat{F}^{\prime}\right)\left(f\left(\hat{\theta}_{0}\right)-g\left(\hat{\theta}_{1}\right)\right),
$$

where $\hat{F}$ is the matrix of derivatives $\frac{\partial f\left(\theta_{0}\right)}{\partial \theta_{0}}$, evaluated at $\hat{\theta}_{0}$. 


\section{APPENDIX B: SUPPLEMENTARY TABLE}

Table B.1 Summary statistics of variables used in estimation of substitution effects

\begin{tabular}{|c|c|c|c|c|c|c|}
\hline Variable & Year & $N$ & Mean & $\begin{array}{l}\text { Standard } \\
\text { Deviation }\end{array}$ & Minimum & Maximum \\
\hline \multirow{3}{*}{$\begin{array}{l}\text { Area of forests and grassland } \\
\text { converted to farmland } \\
\text { (thousand ha) }\end{array}$} & 1986-1995 & 2,234 & 2.93 & 11.01 & 0 & 318.31 \\
\hline & 1995-2000 & 2,234 & 3.93 & 9.59 & 0 & 214.01 \\
\hline & 2000-2005 & 2,234 & 3.12 & 7.31 & 0 & 127.73 \\
\hline \multirow{3}{*}{$\begin{array}{l}\text { Area of developed farmland } \\
\text { (thousand ha) }\end{array}$} & 1986-1995 & 2,234 & 0.27 & 0.99 & 0 & 26.19 \\
\hline & $1995-2000$ & 2,234 & 0.14 & 0.32 & 0 & 4.05 \\
\hline & $2000-2005$ & 2,234 & 0.84 & 1.65 & 0 & 28.83 \\
\hline \multirow{3}{*}{$\begin{array}{l}\text { Rural population } \\
\text { (million people) }\end{array}$} & 1986-1995 & 2,234 & 0.385 & 0.291 & 0.001 & 2.314 \\
\hline & 1995-2000 & 2,234 & 0.401 & 0.303 & 0.004 & 2.709 \\
\hline & 2000-2005 & 2,234 & 0.407 & 0.306 & 0.003 & 2.140 \\
\hline \multirow{3}{*}{$\begin{array}{l}\text { Ratio of per capita urban-to- } \\
\text { rural GDP }\end{array}$} & 1986-1995 & 2,234 & 10.9 & 12.0 & 0.03 & 160.4 \\
\hline & 1995-2000 & 2,234 & 12.5 & 12.9 & 0.12 & 168.5 \\
\hline & 2000-2005 & 2,234 & 15.8 & 18.4 & 0.20 & 338.2 \\
\hline \multirow[t]{3}{*}{ Elevation (km) } & 1986-1995 & 2,234 & 0.67 & 0.78 & -0.08 & 4.81 \\
\hline & 1995-2000 & 2,234 & 0.67 & 0.77 & -0.05 & 4.81 \\
\hline & 2000-2005 & 2,234 & 0.67 & 0.78 & 0.00 & 4.81 \\
\hline \multirow{3}{*}{$\begin{array}{l}\text { Medium slope } \\
\text { ( } 0-1 \text { dummy, where } 1 \\
\text { indicates } 5 \% \leq \text { slope } \leq 15 \%)\end{array}$} & 1986-1995 & 2,234 & 0.59 & 0.40 & 0 & 1 \\
\hline & $1995-2000$ & 2,234 & 0.57 & 0.40 & 0 & 1 \\
\hline & 2000-2005 & 2,234 & 0.59 & 0.38 & 0 & 1 \\
\hline \multirow{3}{*}{$\begin{array}{l}\text { High slope } \\
\text { (0-1 dummy, where } 1 \\
\text { indicates slope > 15\%) }\end{array}$} & 1986-1995 & 2,234 & 0.42 & 0.38 & 0 & 1 \\
\hline & 1995-2000 & 2,234 & 0.40 & 0.39 & 0 & 1 \\
\hline & 2000-2005 & 2,234 & 0.41 & 0.37 & 0 & 1 \\
\hline \multirow[t]{3}{*}{ Precipitation (thousand mm) } & 1986-1995 & 2,234 & 0.76 & 0.41 & 0.01 & 1.79 \\
\hline & $1995-2000$ & 2,234 & 0.77 & 0.44 & 0.01 & 1.75 \\
\hline & 2000-2005 & 2,234 & 0.93 & 0.48 & 0.04 & 2.37 \\
\hline \multirow[t]{3}{*}{ Temperature $\left({ }^{\circ} \mathrm{C}\right)$} & 1986-1995 & 2,234 & 12.13 & 5.68 & -7.26 & 24.04 \\
\hline & $1995-2000$ & 2,234 & 12.54 & 5.65 & -6.52 & 24.33 \\
\hline & $2000-2005$ & 2,234 & 12.94 & 5.51 & -1.81 & 25.23 \\
\hline
\end{tabular}

Source: Author's calculations.

Note: $\quad$ ha $=$ hectare; GDP $=$ gross domestic product; $\mathrm{km}=$ kilometer; $\mathrm{mm}=$ millimeter; ${ }^{\circ} \mathrm{C}=\operatorname{degrees}$ Celsius. 


\section{REFERENCES}

Alonso, W. 1964. Location and Land Use. Cambridge, MA, US: Harvard University Press.

Alterman, R. 1997. "The Challenge of Farmland Preservation: Lessons from a Six-Nation Comparison.” Journal of the American Planning Association 63 (2): 220-243.

American Farmland Trust. 1997. Saving American Farmland: What Works. Northhampton, MA, US: AFT Publications Division, Herrick Hill.

Arnott, R., and F. Lewis. 1979. “The Transition of Land to Urban Use.” Journal of Policy Economy 87 (1): 161169.

Bengston, D. N., J. O. Fletcher, and K. C. Nelson. 2004. "Public Policies for Managing Urban Growth and Protecting Open Space: Policy Instruments and Lessons Learned in the United States." Landscape and Urban Planning 69: 271-286.

Bills, N. L., and R. N. Boisvert. 1987. "New York's Experience in Farmland Retention through Agricultural Districts and Use-Value Assessment." In Sustaining Agriculture Near Cities, edited by W. Lockeretz, 231-250. Ankeny, IA, US: Soil and Water Conservation Society.

Capozza, D., and R. Helsley. 1989. "The Fundamentals of Land Prices and Urban Growth.” Journal of Urban Economics 26: 295-306.

Cox, D. R. 1961. “Tests of Separate Families of Hypotheses.” Proceedings of the Fourth Berkeley Symposium on Mathematical Statistics and Probability 1: 105-123.

1962. "Further Results on Tests of Separate Families of Hypotheses." Journal of the Royal Statistical Society, Series B, 24: 406-424.

Daniels, T. 1998. "The Purchase of Development Rights, Agricultural Preservation and Other Land Use Policy Tools: The Pennsylvania Experience.” In Increasing Understanding of Public Problems and Policies: Proceedings of the 1998 National Public Policy Education Conference, edited by D. P. Ernestes and D. M. Hicks, 34-44. Oak Brook, IL, US: Farm Foundation.

Deng, X., J. Huang, S. Rozelle, and E. Uchida. 2006. "Cultivated Land Conversion and Potential Agricultural Productivity in China." Land Use Policy 23: 372-384.

- 2008. "Growth, Population and Industrialization, and Urban Land Expansion of China." Journal of Urban Economics 63: 96-115.

Ding, C. 2003. "Land Policy Reform in China: Assessment and Prospects." Land Use Policy 20 (2): 109-120.

Fischer, G., M. Shah, H. van Velthuizen, and F. Nachtergaele. 2001. Global Agro-ecological Assessment for Agriculture in the 21st century. IIASA Research Report 02-02, International Institute for Applied Systems Analysis, Laxenburg, Austria.

Fischer, G., F. Nachtergaele, S. Prieler, H.T. van Velthuizen, L. Verelst, D. Wiberg. 2008. Global Agro-ecological Zones Assessment for Agriculture (GAEZ 2008). IIASA, Laxenburg, Austria and FAO, Rome, Italy.

Greene, W. 1994. Accounting for Excess Zeros and Sample Selection in Poisson and Negative Binomial Regression Models. NYU Working Paper No. EC-94-10. New York: New York University. http://ssrn.com/abstract=1293115.

Howe, D. 1994. “A Research Agenda for Oregon Planning: Problems and Practices for the 1990s." In Planning the Oregon Way: A Twenty-Year Evaluation, edited by C. Abbott, D. Howe, and S. Adler, 275-290. Corvallis, OR, US: Oregon State University Press.

Jacobs, H. M. 1999. "Protecting Agricultural Lands under the Threat of Urbanization: Lessons for Developing Countries from Developed Countries." In Proceedings of International Seminar on Land Policy and Economic Development, 210-227. Taoyuan, Taiwan: International Center for Land Policy Studies and Training. 
Kline, D., and R. J. Alig. 1999. "Does Land Use Planning Slow the Conversion of Forest and Farmlands?" Growth and Change 30: 3-22.

Lambert, D. 1992. "Zero-Inflated Poisson Regression, with an Application to Defects in Manufacturing." Technometrics 34: 1-14.

Lee, J., and Y. Zhu. 2006. "Urban Governance, Neoliberalism and Housing Reform in China." Pacific Review 19 (1): 39-61.

Li, M., J. Wu, and X. Deng. 2013. "Identifying the Drivers of Land Use Change in China: A Spatial Multinomial Logit Model Analysis." Land Economics 89 (4): 632-654.

Lichtenberg, E., and C. Ding. 2008. “Assessing Farmland Protection Policy in China.” Land Use Policy 25: 59-68.

_. 2009. "Local Officials as Land Developers: Urban Spatial Expansion in China." Journal of Urban Economics 66: 57-64.

Liu, J., and Buheaosier. 2000. "Study on Spatial-Temporal Feature of Modern Land-Use Change in China: Using Remote Sensing Techniques.” 第四季研究 [Quarternary Sciences] 20(3): 229-239.

Liu, J., M. Liu, D. Zhuang, Z. Zhang, and X. Deng. 2003. "Study on Spatial Pattern of Land-Use Change in China during 1995-2000." Science in China, Series D, 46: 373-384.

Liu, J., Z. Zhang, X. Xu, W. Kang, W. Zhou, S. Zhang, R. Li, C. Yan, D. Yu, S. Wu, and N. Jiang. 2010. "Spatial Patterns and Driving Forces of Land Use Change in China during the Early 21st Century." Journal of Geographical Sciences 20 (4): 483-494.

Mackinnon, J. G. 1983. "Model Specification Tests against Non-nested Alternatives.” Econometric Review 2: 85110.

Mills, E. 1967. “An Aggregative Model of Resource Allocation in a Metropolitan Area.” American Economic Review, Papers and Proceedings 57: 197-210.

MPSC (Ministry of Public Security of China). 1996. China Counties and Cities Population Yearbook. Beijing: Chinese Public Security University Press.

. 2001. China Counties and Cities Population Yearbook. Beijing: Chinese Public Security University Press.

Muth, R. 1969. City and Housing. Chicago: University of Chicago Press.

NBSC (National Bureau of Statistics of China). 2010. China Statistical Yearbook. Beijing: China Statistical Press.

_.2001. China Socio-Economic Statistical Yearbook for China's Counties and Cities. Beijing: China Statistical Press.

OECD (Organization for Economic Co-operation and Development). 1995. The Chinese Grain and Oilseed Sector: Major Changes under Way. Paris: OECD.

Pesaran, M. H., and A. S. Deaton. 1978. "Testing Non-nested Nonlinear Regression Models." Econometrica 46 (3): $677-694$.

Pfeffer, J., and M. B. Lapping. 1994. "Farmland Preservation, Development Rights and the Theory of the Growth Machine: The Views of Planners.” Journal of Rural Studies 10: 233-248.

Standing Committee of the Ninth National People's Congress of the People's Republic of China. 1998. Land Administration Law of the People's Republic of China, 1st amended version. Beijing: Standing Committee of the Ninth National People's Congress of the People's Republic of China.

State Council of the People's Republic of China. 1994. Basic Farmland Protection Regulation. Beijing: State Council of the People's Republic of China.

Wu, J. 2000. "Slippage Effects of the Conservation Reserve Program." American Journal of Agricultural Economics 82 (4): 979-992.

Wu, J., and S. Cho. 2007. "The Effect of Local Land Use Regulations on Urban Development in the Western United States." Regional Science and Urban Economics 37: 69-86.

Yang, H., and X. Li. 2000. "Cultivated Land and Food Supply in China.” Land Use Policy 17 (2): 73-88. 


\section{RECENT IFPRI DISCUSSION PAPERS}

\section{For earlier discussion papers, please go to www.ifpri.org/pubs/pubs.htm\#dp. All discussion papers can be downloaded free of charge.}

1347. Women's individual and joint property ownership: Effects on household decisionmaking. Cheryl Doss, Sung Mi Kim, Jemimah Njuki, Emily Hillenbrand, and Maureen Miruka, 2014.

1346. Can smallholder fruit and vegetable production systems improve household food security and nutritional status of women?: Evidence from rural Uganda. Nassul Kabunga, Shibani Ghosh, and Jeffrey K. Griffiths, 2014.

1345. Intellectual property rights, technology diffusion, and agricultural development: Cross-country evidence. David J. Spielman and Xingliang Ma, 2014.

1344. Market interdependence and volatility transmission among major crops. Cornelis Gardebroek, Manuel A. Hernandez, and Miguel Robles, 2014.

1343. Importance of rice research and development in rice seed policies: Insights from Nigeria. Hiroyuki Takeshima, 2014.

1342. Can transfer programs be made more nutrition sensitive? Harold Alderman, 2014.

1341. The impact of cash and food transfers: Evidence from a randomized intervention in Niger. John Hoddinott, Susanna Sandström, and Joanna Upton, 2014.

1140. How does climate change alter agricultural strategies to support food security? Philip Thornton and Leslie Lipper, 2014.

1339. Public-sector agricultural research priorities for sustainable food security: Perspectives from plausible scenarios. Gerald C. Nelson and Dominique van der Mensbrugghe, 2014.

1338. Migration, local off-farm employment, and agricultural production efficiency: Evidence from China. Jin Yang, Hui Wang, Songqing Jin, Kevin Chen, Jeffrey Riedinger, and Peng Chao, 2014.

1337. Farmers' preferences for climate-smart agriculture: An assessment in the Indo-Gangetic Plain. Garima Taneja, Barun Deb Pal, Pramod K. Joshi, Pramod K. Aggarwal, N. K. Tyagi, 2014.

1336. An empirical examination of the dynamics of varietal turnover in Indian wheat. Vijesh V. Krishna, David J. Spielman, Prakashan C. Veettil, and Subash Ghimire, 2014.

1335. Agricultural policy processes and the youth in Malawi. Mariam A. T. J. Mapila, 2014.

1334. Can cash transfers promote the local economy?: A case study for Cambodia. Stephanie Levy and Sherman Robinson, 2014.

1333. Gender, control, and crop choice in northern Mozambique. Alan de Brauw, 2014.

1332. Employment risk and job-seeker performance. Susan Godlonton, 2014.

1331. Food prices and poverty reduction in the long run. Derek Headey, 2014.

1330. Impact of Ghana's Agricultural Mechanization Services Center Program. Samuel Benin, 2014.

1329. Aid effectiveness: How is the L'Aquila Food Security Initiative doing? Samuel Benin, 2014.

1328. Improved dairy cows in Uganda: Pathways to poverty alleviation and improved child nutrition. Nassul Kabunga, 2014.

1327. A comparative analysis of global cropping systems models and maps. Weston Anderson, Liangzhi You, Stanley Wood, Ulrike Wood-Sichra, and Wenbin Wu, 2014.

1326. Population pressure and livelihood dynamics: Panel evidence from Bangladesh. Shahidur Rashid, Nigussie Tefera, Solomon Lemma, and Mohammad Yunus, 2014.

1325. Changing sources of growth in Indian Agriculture: Implications for regional priorities for accelerating agricultural growth. Pratap S. Birthal, Pramod K. Joshi, Digvijay S. Negi, and Shaily Agarwal, 2014.

1324. Risk and ambiguity preferences and the adoption of new agricultural technologies: Evidence from field experiments in rural India. Patrick S. Ward and Vartika Singh, 2014.

1323. Land, Assets, and Livelihoods: Gendered Analysis of Evidence from Odisha State in India. Vivien Savath, Diana Fletschner, Amber Peterman, and Florence Santos, 2014. 
INTERNATIONAL FOOD POLICY RESEARCH INSTITUTE

www.ifpri.org

IFPRI HEADQUARTERS

2033 K Street, NW

Washington, DC 20006-1002 USA

Tel.: +1-202-862-5600

Fax: +1-202-467-4439

Email: ifpri@cgiar.org 